\title{
Innovative Immunization Strategies for Antivenom Development
}

\author{
Erick Bermúdez-Méndez ${ }^{1}\left(\mathbb{D}\right.$, Albert Fuglsang-Madsen ${ }^{2,3}$, Sofie Føns ${ }^{2}{ }^{\circledR}$, Bruno Lomonte ${ }^{4}(\mathbb{D}$, \\ José María Gutiérrez ${ }^{4}(\mathbb{i})$ and Andreas Hougaard Laustsen ${ }^{2, *}$ (i) \\ 1 Facultad de Farmacia, Universidad de Costa Rica, San José 11501-2060, Costa Rica; \\ erick.bermudez_m@ucr.ac.cr \\ 2 Department of Biotechnology and Biomedicine, Technical University of Denmark, DK-2800 Kongens Lyngby, \\ Denmark; albertfuglsang@outlook.com (A.F.M); sofie.foens@gmail.com (S.F.) \\ 3 Department of Biology, University of Copenhagen, DK-2200 København N, Denmark \\ 4 Instituto Clodomiro Picado, Facultad de Microbiología, Universidad de Costa Rica, San José 11501-2060, \\ Costa Rica; bruno.lomonte@ucr.ac.cr (B.L.); jose.gutierrez@ucr.ac.cr (J.M.G.) \\ * Correspondence: ahola@bio.dtu.dk; Tel.: +45-2988-1134
}

Received: 29 September 2018; Accepted: 30 October 2018; Published: 2 November 2018

\begin{abstract}
Snakes, scorpions, and spiders are venomous animals that pose a threat to human health, and severe envenomings from the bites or stings of these animals must be treated with antivenom. Current antivenoms are based on plasma-derived immunoglobulins or immunoglobulin fragments from hyper-immunized animals. Although these medicines have been life-saving for more than 120 years, opportunities to improve envenoming therapy exist. In the later decades, new biotechnological tools have been applied with the aim of improving the efficacy, safety, and affordability of antivenoms. Within the avenues explored, novel immunization strategies using synthetic peptide epitopes, recombinant toxins (or toxoids), or DNA strings as immunogens have demonstrated potential for generating antivenoms with high therapeutic antibody titers and broad neutralizing capacity. Furthermore, these approaches circumvent the need for venom in the production process of antivenoms, thereby limiting some of the complications associated with animal captivity and venom collection. Finally, an important benefit of innovative immunization approaches is that they are often compatible with existing antivenom manufacturing setups. In this review, we compile all reported studies examining venom-independent innovative immunization strategies for antivenom development. In addition, a brief description of toxin families of medical relevance found in snake, scorpion, and spider venoms is presented, as well as how biochemical, bioinformatic, and omics tools could aid the development of next-generation antivenoms.
\end{abstract}

Keywords: animal envenoming; antivenom development; immunization; synthetic epitope; recombinant toxin; DNA immunization; neutralization; omics technologies; bioinformatics; high-density peptide microarray technology; snakebite envenoming; scorpion envenoming; spider envenoming

Key Contribution: An exhaustive compilation of the studies exploring innovative immunization strategies for antivenom development, mainly focusing on venom-independent approaches.

\section{Introduction}

Snakes, scorpions, and spiders belong to a diverse group of venomous animals capable of causing severe envenomings through their bite or sting, which are considered a serious public health issue in many parts of the world [1-3]. Of these, snakebite envenoming is considered as having the highest 
impact, causing approximately 1.8-2.7 million cases annually, leading to $81,000-138,000$ deaths [4-6]. Furthermore, it has been estimated that scorpion stings are responsible for approximately 1.2 million envenomings each year, of which more than 3250 people die [7], whereas no reliable epidemiological data for spider bites is available in the literature.

Since the first reports on antivenom development in 1894 [8], parenteral administration of plasma-derived antivenoms of animal origin has been the only specific therapeutic option for the treatment of envenomings by animal bites and stings [3,9]. At present, several public and private laboratories around the world manufacture such antivenoms. However, in some countries, these products are not readily available or are unaffordable for the victims [10-12]. Limited availability and affordability issues are, in part, a consequence of the laborious and costly procedure of the traditional antivenom manufacturing process, which requires keeping venomous animals in captivity and milking them to obtain their venoms [13-15]. Venom procurement becomes further complicated in cases where animals deliver low amounts of venom or when the animals do not thrive in captivity $[13,16]$.

Even though antivenoms have generally proven effective and have saved thousands of lives worldwide, various intrinsic features from either the manufacturing process or the nature of the antivenom may restrict their clinical efficacy. Antivenom production involves the repeated immunization (for months to years) of large mammals (mostly horses and sheep), followed by purification of the immunoglobulin G (IgG) antibodies from the hyper-immunized plasma. IgG purification is typically carried out by salting-out procedures using either caprylic acid or ammonium sulfate $[9,14,17-19]$. Additionally, most manufacturers produce $\mathrm{F}\left(\mathrm{ab}^{\prime}\right)_{2}$ antivenoms by introducing a pepsin digestion step [20]. As a result, antivenoms consist of a mixture of both toxin-neutralizing antibodies and antibodies against all other antigens that the immunized animal has come across throughout its life, resulting in a low titer of therapeutically relevant antibodies [21,22]. CroFab [23], an antivenom purified by affinity chromatography using snake venom coupled to a matrix, is the only exception. However, affinity purification greatly increases production costs. Moreover, the toxicity of some venoms largely depends on poorly immunogenic low molecular mass toxins. This discrepancy between toxicity and immunogenicity generates an unbalanced antibody content in antivenoms, with a major fraction of the antibodies targeting immunogenic, but non-toxic, high molecular mass components, and a minor fraction of the antibodies targeting highly toxic, but poorly immunogenic components [24-28].

In order to reduce the public health burden caused by bites or stings of venomous animals, current biotechnological tools have been applied to improve antivenom production (reviewed in [29-31]). One useful approach has focused on antivenom production independent of venom use. Here, several modern immunization techniques have been explored, such as the utilization of synthetic peptide epitopes, recombinant toxins (or toxoids), consensus toxins, and DNA strings. Apart from leaving aside venom use and, consequently, the need to keep venomous animals in captivity, antivenom production based on new immunization approaches is considered quite feasible, since it can readily be adapted to current manufacturing platforms without introducing significant modifications. In addition, new immunization approaches may offer the possibility of exclusively using clinically relevant toxins for the immunization procedure, likely leading to a higher titer of therapeutically relevant antibodies and an increased antivenom neutralizing capacity. Such higher titers might, in turn, possibly result in safer products (with lower propensity to cause adverse reactions), as the total dosage of antibodies (which are heterologous proteins) required for venom neutralization would be lower. Moreover, since antivenoms obtained using novel immunization strategies do not differ in nature from traditional antivenoms, regulatory approval processes should not restrain their introduction into the market. However, despite these advantages, inherent batch-to-batch variation is still expected, as a consequence of the dependence on the immune system of immunized production animals [32].

In this paper, we present a comprehensive overview of all studies testing innovative venom-independent immunization strategies for antivenom development. Some examples of alternative venom-dependent approaches are also included. In addition, a summary of the clinically 
most important toxin families in snake, scorpion, and spider venoms is presented, as well as how complementary biochemical, bioinformatic, and omics tools can be exploited to design cutting-edge immunization protocols. Novel approaches in the therapy of envenomings, such as the development of toxin inhibitors based on aptamers, small molecules, or recombinant antibodies (or fragments thereof) of human or camelid origin are beyond the scope of this review, and can be found elsewhere [32-37].

\section{Clinically Important Toxin Families}

Envenoming by snakes, scorpions, and spiders can result in a wide spectrum of pharmacological effects, ranging from localized tissue damage to systemic toxicities. Characteristic toxic effects, which vary depending on the particular venom, include edema, dermonecrosis, myonecrosis, hemolysis, hemorrhage, alterations in coagulation and platelet function, nephrotoxicity, cytotoxicity, and neurotoxicity $[6,38,39]$. These diverse pathological manifestations are a consequence of the complex composition of venoms, constituted by a mixture of enzymatic and non-enzymatic peptidic and proteinaceous toxins, as well as low molecular mass organic and inorganic components [38,40,41].

Not all venom components contribute to the overall venom toxicity. The clinically most relevant toxins (in terms of lethality) can be determined with the Toxicity Score, a parameter that takes into account both potency (median lethal dose, $\mathrm{LD}_{50}$ ) and abundance of the individual toxins [27,42]. Studies on the efficacy of antivenom in neutralizing key venom toxins have underscored a discrepancy between toxicity and immunogenicity $[24,27,43,44]$. Many immunogenic venom components have been shown to be irrelevant for the overall toxicity, while some highly toxic venom components are poorly immunogenic, or even immunosuppressive [45], with existing antivenoms sometimes being unable to effectively neutralize them $[24,27,44]$. Generally, immunogenicity correlates with the molecular size of the toxin, with toxins of low molecular mass being less immunogenic compared to high molecular mass components $[24,27,43,44]$. Knowledge on venom composition, toxicity of particular components, and toxin immunogenicity is thus imperative for antivenom development. Hence, the identification of the most relevant toxins in venoms of high medical impact is of paramount relevance for the design of optimal mixtures of toxins for immunization. In the following, a brief summary of the clinically most important snake, scorpion, and spider toxin families is presented.

\subsection{Snake Venom Toxin Families}

Despite the complexity of snake venoms, most of the medically relevant snake toxins have been found mainly to belong to a handful of toxin families (Figure 1a) [46-48]. The clinically most important toxin families include (i) three-finger toxins (3FTxs), (ii) phospholipases $\mathrm{A}_{2}\left(\mathrm{PLA}_{2} \mathrm{~s}\right)$, (iii) snake venom metalloproteinases (SVMPs), and (iv) snake venom serine proteinases (SVSPs) [46]. Additionally, (v) dendrotoxins will also briefly be presented due to their importance for the notorious mamba species [49].

\subsubsection{Three-Finger Toxins}

3FTxs are found in the venoms of elapids (including sea snakes and terrestrial elapids), 'colubrids' (sensu lato), and few viperids [46]. These toxins are non-enzymatic polypeptides of typically 60-74 amino acid residues with a shared common scaffold of three $\beta$-stranded loops extending from a central, hydrophobic core with four conserved disulfide bonds. Members of the family include the neurotoxic $\alpha$-toxins, $\mathrm{k}$-toxins, and muscarinic toxins that target muscle nicotinic cholinergic receptors (nAChRs), neuronal nAChRs, and subtypes of muscarinic receptors, respectively [46]. Another class of 3FTxs are the fasciculins, which inhibit the enzyme acetylcholinesterase, thus preventing acetylcholine from being broken down, leading to its accumulation at the synapse. This interference of neuromuscular inhibition induces fasciculations in muscles [46]. In addition, some elapid venoms contain 3FTxs, which exert cytotoxic activity, hence causing tissue necrosis [50]. 
(a) Snake toxins

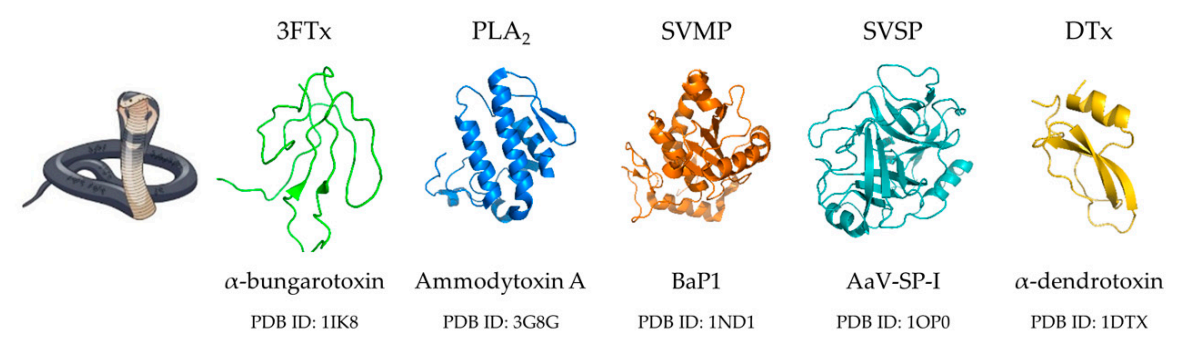

(b) Scorpion toxins

(c) Spider toxins

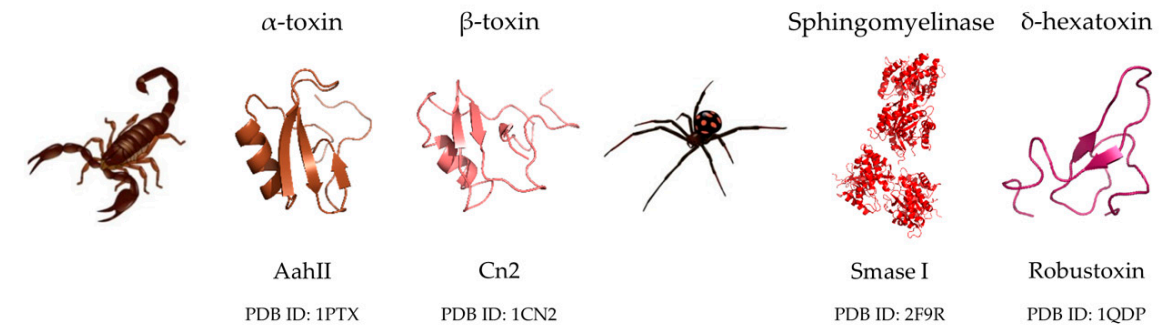

Figure 1. 3D structures of representative toxins belonging to each clinically relevant toxin family. (a) Snake toxins. (b) Scorpion toxins. (c) Spider toxins. 3FTx, three-finger toxin; $\mathrm{PLA}_{2}$, phospholipase $\mathrm{A}_{2}$; SVMP, snake venom metalloproteinase; SVSP, snake venom serine proteinase; DTx, dendrotoxin; BaP1, Bothrops asper P-I-type metalloproteinase; AaV-SP-I, Agkistrodon actus serine proteinase I; AahII, Androctonus australis hector toxin II; Cn2, Centruroides noxius Hoffmann toxin 2; Smase I, Loxosceles laeta sphingomyelinase I; PDB ID, Protein Data Bank accession ID. Images were created using PyMOL (The PyMOL Molecular Graphics System, Version 2.2 Schrödinger, LLC).

\subsubsection{Phospholipases $A_{2}$}

$\mathrm{PLA}_{2} \mathrm{~s}$ are found in the venoms of Viperidae, Elapidae, and Colubridae (sensu lato) snakes [6]. The lengths of $\mathrm{PLA}_{2} \mathrm{~s}$ vary from 119-134 amino acids, and they share a common scaffold of four main helices with seven intrachain disulfide bonds [51]. PLA 2 s exert a wide variety of toxic activities, including myotoxicity and neurotoxicity, either dependent or independent of their catalytic activity [51, 52]. The toxicity is caused by an initial plasma membrane perturbation, which promotes a large increase in the cytosolic $\mathrm{Ca}^{2+}$ concentration that leads to degenerative events, including impairment of mitochondrial function. Some $\mathrm{PLA}_{2} \mathrm{~S}$ target presynaptic nerve terminals in the peripheral nervous system causing paralysis, whereas others target both the nervous and muscular systems, or act on skeletal muscles. The latter cause irreversible muscle damage, which can induce systemic myotoxicity, e.g., rhabdomyolysis with myoglobinuria, leading to acute kidney injury [51]. Venom $\mathrm{PLA}_{2} \mathrm{~s}$ also exert other activities, including inhibition of coagulation, intravascular hemolysis, and are strongly pro-inflammatory [52].

\subsubsection{Snake Venom Metalloproteinases}

Zinc-dependent SVMPs are a major component of venoms in the snake family Viperidae, but are also present in species of Colubridae (sensu lato) and Elapidae [53,54]. SVMPs can be divided into three classes (P-I, P-II, and P-III), depending on their domain composition, with molecular masses of 20-30 kDa, 30-60 kDa, and 60-100 kDa, respectively [54]. SVMPs induce local and systemic hemorrhage by hydrolyzing components of the extracellular matrix, including collagen IV in the basement membrane of capillary blood vessels $[6,53]$. Their cleavage of cell-cell junctions also promotes the mechanical weakening of the microvessel wall, leading to extravasation [6]. In addition, SVMPs cause myonecrosis, blistering, dermonecrosis, edema, and coagulopathies, and like PLA ${ }_{2}$ s, induce pain and inflammation [53]. 


\subsubsection{Snake Venom Serine Proteinases}

SVSPs are found in venoms of the snake families Viperidae, Elapidae, and Colubridae (sensu lato) [55]. The molecular masses of SVSPs vary between 26 and $67 \mathrm{kDa}$, depending on the extent of glycosylation. SVSPs are trypsin-like enzymes, but with variable macromolecular substrate specificity, acting by a common catalytic mechanism that includes a reactive serine residue [55]. SVSPs interfere with blood coagulation, fibrinolysis, blood pressure, and platelet aggregation. SVMPs and SVSPs act in the coagulation cascade, which can promote intravascular coagulation, but more often lead to consumption coagulopathy [6]. The resulting incoagulability can contribute to systemic bleeding, especially in venoms that simultaneously contain hemorrhagic toxins $[6,55]$.

\subsubsection{Dendrotoxins}

Dendrotoxins are a family of toxins found among the Dendroaspis (mamba) snakes of the family Elapidae. They consist of 57-60 amino acid residues crosslinked by three disulfide bonds, and show structural homology to Kunitz-type serine protease inhibitors, albeit with different pharmacological effects. Dendrotoxins exert their effects by blocking specific subtypes of voltage-dependent potassium channels (Kv1 subfamily in neurons) that facilitate acetylcholine release at peripheral synapses, resulting in an excitatory effect $[49,56]$.

\subsubsection{Minor Snake Venom Toxin Families}

The toxin families discussed above represent the most important toxins in snake venoms from the pathological and pathophysiological standpoint. However, snake venoms contain various other proteins with lower contribution to venom toxicity. These minor snake venom protein families include C-type lectin-like proteins, cysteine-rich secretory proteins (CRISPs), L-amino acid oxidases, low molecular mass myotoxins (e.g., crotamine), vasoactive peptides, disintegrins, hyaluronidases, natriuretic peptides, and sarafotoxins, among others, which are outside the scope of this paper and have been described elsewhere $[6,57]$.

\subsection{Scorpion Venom Toxins}

The clinically most relevant toxins in scorpion venoms are the scorpion $\alpha$ and $\beta$-toxins, both of which are composed of 61-76 amino acid residues cross-linked by four disulfide bonds (Figure 1b). These neurotoxins typically adopt a highly conserved three-dimensional structure comprising an $\alpha$-helix and three or four-stranded anti-parallel $\beta$-sheets with high chemical and thermal stability. These toxins interact with multiple sites on voltage-gated sodium ( $\mathrm{Na}_{\mathrm{V}}$ ) channels [39,58], reflecting their distinct pharmacological effects and mechanisms of action. The $\alpha$-toxins (also known as Old World scorpion toxins) target neurotoxin binding site 3, which is localized on the extracellular surface of the $\mathrm{Na}_{V}$ channels and impede fast inactivation [58]. Consequently, this leads to prolonged depolarization and excessive neuronal activity. The resulting sympathetic excitation and the endogenous release of catecholamines can cause severe systemic effects, including myocardial injury, pulmonary edema, and cardiogenic shock [39]. In contrast, the $\beta$-toxins (also known as New World scorpion toxins) target neurotoxin binding site 4 . Electrophysiological studies have revealed that the $\beta$-toxins cause a hyperpolarizing shift in the voltage dependence of activation, thus lowering the threshold for action potential firing [58]. Other neurotoxins in scorpion venoms act on voltage-gated potassium and calcium channels. However, these toxins appear to be less important in human envenoming [39]. Severe envenoming is often caused by scorpions of the Buthidae family, nonetheless, in most cases of scorpion stings, only localized pain and minimal systemic involvement follow [39]. Additionally, scorpion venoms contain a range of enzymatic toxins, such as hyaluronidases, metalloproteinases, and phospholipases [33]. 


\subsection{Spider Venom Toxins}

In the majority of human envenoming cases, spider bites only cause minor effects, although worldwide a few groups of spiders cause more significant effects and are thus medically significant. These groups include (i) the widow spiders (Latrodectus spp.), (ii) the recluse spiders (Loxosceles spp.), (iii) the Australian funnel-web spiders (Atrax spp. and Hadronyche spp.), and (iv) the armed or banana spiders (Phoneutria spp.) from Brazil [59,60]. In the following, a brief description of representative toxins from each group will be given.

\subsection{1. $\alpha$-Latrotoxin}

$\alpha$-Latrotoxin $(\alpha$-LTX) is a $130 \mathrm{kDa}$ neurotoxin found in Latrodectus venoms that appears to be responsible for the clinical effects in humans resulting in the envenoming syndrome 'latrodectism' $[60,61]$. $\alpha$-LTX induces neurotransmitter vesicle exocytosis via both $\mathrm{Ca}^{2+}$-dependent and independent mechanisms [61]. Latrodectism is characterized by diaphoresis and pain developing gradually and lasting for hours to days. In case of systemic envenoming, non-specific symptoms such as nausea, vomiting, headache, and fatigue are common, but latrodectism is rarely life-threatening $[59,60]$.

\subsubsection{Sphingomyelinases $\mathrm{D}$}

Sphingomyelinases D (SMases D) are found in Loxosceles venoms and are considered the key components involved in the development of dermonecrosis, the main manifestation of the cutaneous form of loxoscelism. SMases D are 31-35 kDa enzymes that hydrolyze sphingomyelin in the outer leaflet of mammalian plasma membranes, resulting in the formation of ceramide (Figure 1c) [62]. Local effects of Loxosceles bites vary from small areas of erythema to progression of large areas of ulceration and necrosis that can take months to heal. The often painless bite will in up to $10 \%$ of cases result in severe systemic reactions (viscerocutaneous loxoscelism), including shock, complement-mediated intravascular hemolysis, and renal failure [60,62].

\subsection{3. $\delta$-Hexatoxins}

$\delta$-Hexatoxins ( $\delta$-HXTXs) are homologous neurotoxins of about $4.8 \mathrm{kDa}$, responsible for the severe envenoming symptoms in humans caused by bites of six different funnel-web species (Figure 1c) [63]. Severe systemic envenoming is rare, but the onset of life-threatening effects is rapid. Severe systemic envenoming is characterized by neuromuscular excitation, including paraesthesia and fasciculations, pulmonary edema and massive autonomic stimulation/excitation with generalized diaphoresis, hypersalivation, hyperlacrimation, and hypertension. Without antivenom, further effects like neuromuscular paralysis, coma, hypotension, and multi-organ failure might follow [59]. The $\delta$-HXTXs induce spontaneous repetitive firing and prolongation of action potentials by binding to receptor site 3 on $\mathrm{Na}_{\mathrm{V}}$ channels, slowing the inactivation of the channels and causing a hyperpolarizing shift of the voltage dependence of activation [61].

\subsection{4. $\mathrm{T} \times 2-6$}

Tx2-6 is a small neurotoxin of about $5.3 \mathrm{kDa}$ found in the venom of Phoneutria spiders [64], that like the $\delta$-HXTXs, slows inactivation of $\mathrm{Na}_{\mathrm{V}}$ channels and causes a shift in the hyperpolarized direction of voltage dependence of activation [65]. A bite from the Phoneutria nigriventer spider causes immediate local pain, diaphoresis, piloerection, and erythema. In systemic envenoming cases, non-specific symptoms, such as nausea and vomiting, are observed, as well as autonomic effects, such as tachycardia, hypertension, salivation, and priapism. It can in rare circumstances progress to pulmonary edema [60]. 


\section{Innovative Venom-Independent Immunization Strategies}

To avoid disadvantages associated with conventional antivenom production, while utilizing existing manufacturing platforms, several researchers have studied the use of recombinant or synthetic toxins and peptides, as well as DNA vaccination strategies to raise therapeutically relevant antibodies via immunization procedures (Figure 2). By removing the current need for venom for antivenom production, and hence for keeping collections of venomous animals, the laborious and potentially dangerous work associated with animal handling can largely be circumvented for personnel [66]. However, venom will still be needed for antivenom quality control and research validation to ensure that novel manufactured antivenoms have adequate efficacy. In the following, an exhaustive compilation of novel venom-independent immunization approaches used in the snake, scorpion, and spider antivenom research fields is provided.

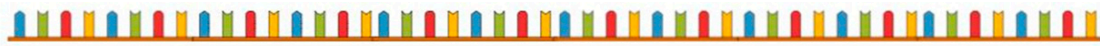

Toxin-encoding DNA sequence
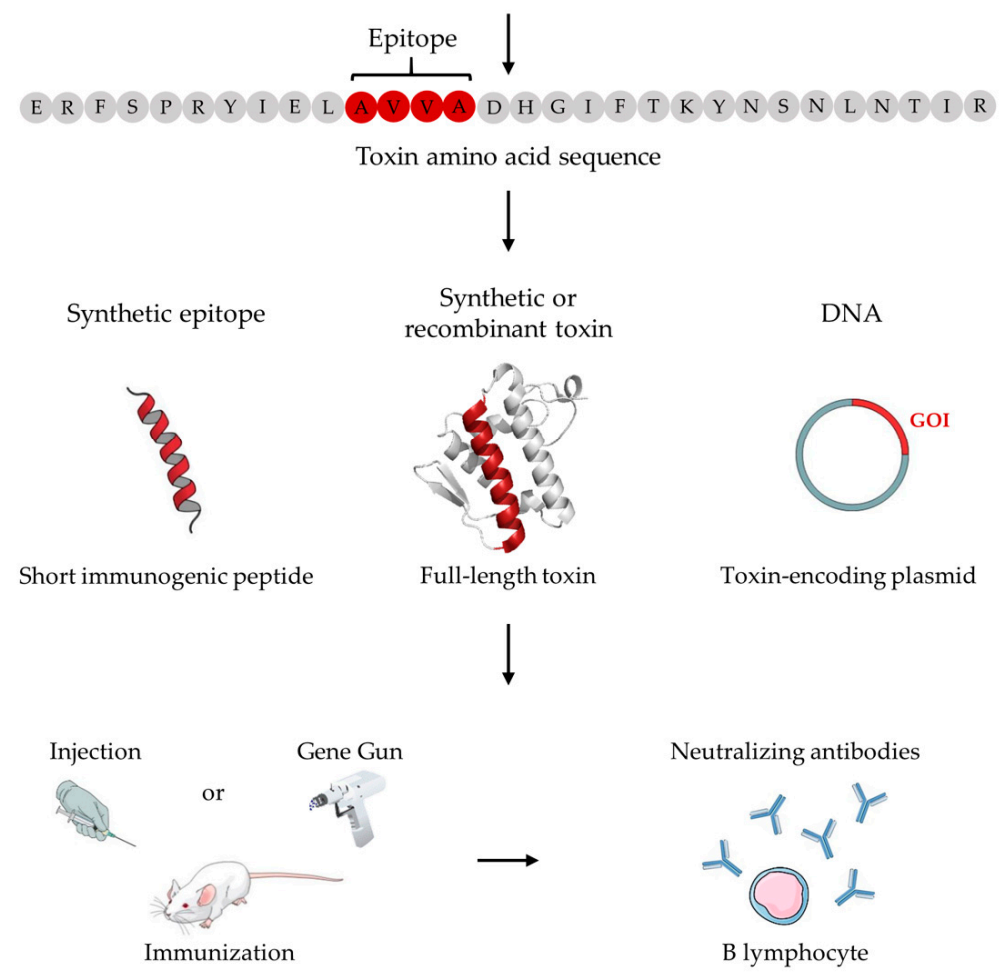

Figure 2. Schematic illustration of the most studied innovative immunization strategies explored for antivenom development. Based on the amino acid sequence of the toxin(s) of interest, short immunogenic peptide(s) or full-length toxin(s), synthetically or recombinantly produced, can be injected into animals. Immunization with the peptide(s) or toxin(s) will lead to a toxin-specific immune response mediated by antibody-producing B lymphocytes. Alternatively, based on the DNA sequence(s) of the toxin(s), a plasmid encoding the gene(s) of interest (GOI) can be transfected into animal cells using a Gene Gun. Following transfection, the animal cells will translate the transcript derived from the plasmid, generating a toxin able to raise a toxin-specific immune response with subsequent production of antibodies by B lymphocytes.

\subsection{Studies within Snake Antivenom Development}

In terms of snake antivenom development using venom-independent immunization techniques, variants of four different approaches have been utilized, summarized in chronological order in Table 1.

The first novel immunization approach concerns the injection of chemically synthesized epitopes of toxins, usually based on epitope mapping studies or epitope prediction using bioinformatic software. 
The antisera raised using these discovered or predicted epitopes have been reported to achieve both partial and complete neutralization in a range of studies. For instance, myotoxicity in mice induced by Bothrops asper myotoxin II (a PLA 2 ) was partially inhibited by antiserum raised against a peptide comprising residues 115-129 (coupled to a diphtheria toxoid) [67], while another study found prolongation of survival when mice immunized with three peptides from the C-terminus of ammodytoxin A (a PLA 2 ) were challenged with Crotalus durissus terrificus and Vipera ammodytes snake venom [68]. In another study, complete neutralization of hemotoxicity was reported when rabbits immunized with synthetic mutalysin II epitopes were challenged with Lachesis muta muta snake venom [69]. Furthermore, in 1991, Čurin-Šerbec et al. immunized rabbits with four individual synthetic peptides (residues 70-78, 106-113, 113-121, and 125-133) from ammodytoxin A conjugated to keyhole limpet hemocyanin (KLH). Rabbit antiserum targeting peptide residues 106-113 completely abolished lethality when naïve mice were challenged with ammodytoxin A, whereas antiserum against residues 113-121 partially blocked toxicity [70]. In another study by Dolimbek and Atassi in 1996, mice were immunized with three peptides from $\alpha$-bungarotoxin (a 3FTx from Bungarus multicinctus venom), which raised an immune response that was reported to neutralize up to $15 \mathrm{LD}_{50} \mathrm{~S}$ of $\alpha$-bungarotoxin injected intravenously in the immunized mice [71]. By further conjugating all three peptides to ovalbumin, the protective capacity exceeded that of the mice immunized with native toxin by almost 2-fold. In a separate study from 2016, Cao and colleagues used the bioinformatic software DNAStar and the online IEDB software (http:/ / tools.immuneepitope.org/bcell/) to predict six linear B-cell epitopes of three major toxins from Deinagkistrodon acutus snake venom. Murine antiserum raised against a tandem protein of the six linear epitopes was able to protect naïve mice against 4 minimum hemorrhagic doses (MHDs). Here, $1 \mathrm{MHD}$ was defined as the dosage of snake venom required to produce a $10 \mathrm{~mm}$ hemorrhagic spot on the visceral side of the back skin, $24 \mathrm{~h}$ after intradermal injection [72].

A second novel immunization approach that has been investigated involves the use of full-length synthetic or recombinant toxins as immunogens, and not only toxin epitopes. Compared to epitopes, both in terms of size and structure, it is likely that these proteins serve as better immunogens due to a closer similarity to the native toxins. A native-like structure is crucial for the generation of antibodies able to recognize the native toxins. Furthermore, no prior epitope mapping study is required. On the other hand, there is a risk of the toxins not folding correctly after chemical synthesis or recombinant expression. One study reported complete neutralization of $2 \mathrm{LD}_{50} \mathrm{~s}$ of Bungarus candidus snake venom injected intravenously in naïve mice, when venom was pre-incubated with murine antiserum generated by immunization with $\alpha$ and $\beta$-neurotoxins (from $\alpha$ and $\beta$-bungarotoxin-based RT-PCR and subsequent cloning and protein expression) as immunogens [73]. Furthermore, 3 LD $_{50} \mathrm{~S}$ of a type I $\alpha$-neurotoxin from Micrurus diastema was reported neutralized, when incubated with rabbit antiserum raised against a recombinant $\alpha$-neurotoxin (called rD.H) and injected intravenously in naïve mice [74]. More recently, the investigation of a short-chain consensus $\alpha$-neurotoxin was reported by de la Rosa et al. As $\alpha$-neurotoxins can be difficult to purify from Elapid snake venoms, the sequences of 12 of the most toxic $\alpha$-neurotoxins from venoms in the Elapidae family were used to generate a recombinant consensus toxin, which was used to immunize rabbits. The consensus toxin was shown to antagonize muscular nAChRs, and the raised immune antiserum was demonstrated to recognize the native toxins from the venom of selected Elapid snakes (particular high titers against Micrurus elegans, M. latifasciatus, and M. nigrocinctus snake venom) [75]. In comparison, the study by Guerrero-Garzón and colleagues reported the generation of protective rabbit antiserum through immunization with a recombinant D.H (rD.H) $\alpha$-neurotoxin, capable of neutralizing the lethal activity of three Micrurus neurotoxins (including rD.H) [74]. Considering the relatively low abundance and poor immunogenicity of 3FTxs in Micrurus venoms [43,74,76], supplementing the immunization mixture of Micrurus snake venoms with recombinant 3FTxs might enhance the therapeutic efficacy of the generated antivenom.

Thirdly, mimotopes (i.e., molecules mimicking the structure of toxin epitopes, but with non-identical amino acid sequences) have been developed $[77,78]$. These mimotopes were developed by 
selecting peptides against immobilized monoclonal antibodies that have shown neutralizing capacity, using $k$-mer peptide libraries and phage display technology. Despite the ability of the immobilized antibodies to recognize different peptide-displaying phages, low sequence similarity existed between the original toxin epitopes and the corresponding mimicked epitope [77,78]. Due to their non-toxic nature, immunizing with epitopes or mimotopes has the advantage and opportunity to allow for increased injection dosage, which may often lead to a more efficient immune response. However, a low molecular mass may decrease immunogenicity, which again could be compensated for, by an increase in injection dosage or by coupling the immunizing peptides with high molecular mass proteins.

Lastly, avoiding chemical synthesis or recombinant expression (with subsequent purification steps), several studies have looked into the opportunity of using DNA immunization. Here, the use of a Gene Gun to inject DNA (bound to gold or tungsten beads) into the animal that is to be immunized has been reported. The injection targets epidermal cells in the abdominal region, which then express and display epitopes for $\mathrm{T}$ helper $2\left(\mathrm{~T}_{\mathrm{H}} 2\right)$ cells to respond to [79-81]. From studies exploring DNA immunization in the snake antivenom field, both antisera with lower $[66,79,82]$ and higher $[81,83]$ neutralization capacities compared to conventional antisera have been reported. Wagstaff and colleagues demonstrated that a mouse antiserum raised using an Echis ocellatus SVMP multiepitope DNA string had better neutralization capacity in mice than an antiserum raised in rabbits by whole E. ocellatus venom immunization [83]. Azofeifa-Cordero and co-workers reported partial neutralization of hemorrhage induced by the rattlesnake Crotalus durissus durissus venom by immunizing with DNA of a P-III type SVMP [84]. In a study by Pergolizzi et al. in 2004, it was demonstrated that immunization by intravenous administration of either a modified $\alpha$-cobratoxin plasmid alone or delivered by a replication-deficient adenovirus vector conferred protection to mice $(100 \%$ survival rate), when challenged intravenously with $1 \mathrm{LD}_{80}$ of $\alpha$-cobratoxin from Naja kaouthia [85]. Interestingly, one study reported the combined use of DNA injection followed by immunization with recombinant toxins in mice. Here, $60 \%$ survival rate in naïve mice was achieved when mice were challenged intraperitoneally with $3 \mathrm{LD}_{50} \mathrm{~s}$ of Micrurus corallinus snake venom pre-incubated with the generated murine antiserum [66].

One of the challenges faced by DNA vaccines/immunization for human use has been insufficient immune responses, despite success in pre-clinical models [86]. Although the antivenom field does not rely on conferring an active vaccination of humans, DNA vaccination has great potential as an immunization technique to obtain exogenous antibodies to be used for envenoming therapy [87]. However, when scaling up from murine models to larger production animals, high IgG titers have failed to be achieved [87]. Some studies have tried to compensate for insufficient immune response in production animals by priming with a DNA immunization and boosting with recombinant proteins $[66,88]$, thus lowering the required amount of protein antigen. DNA priming has also been reported for HIV vaccination [89]. Alternatively, combining DNA immunization with appropriate adjuvants also seems a feasible immunization approach for production of antivenom. A future step in this direction may be inspired by development in other fields, where peptides or antibodies are incorporated in liposomes for targeted payload delivery [90-94]. In this way, the efficacy of the immune response may increase by directly targeting professional antigen-presenting cells (APCs) or T helper cells, instead of having antigen presentation by abdominal epidermal cells targeted by Gene Gun DNA injection.

By relying on DNA sequences rather than synthetically or recombinantly produced peptides or toxins for immunization, less antigen is needed, as each DNA molecule can yield many antigen molecules after translation. It may also prove less toxic for the production animals by lowering peak exposure to toxins, thereby conferring the possibility of utilizing a high DNA immunization dosage, potentially providing a stronger immune response [87]. In the future, this immunization approach might also be further improved by adapting successful approaches from the fields of gene therapy and DNA vaccination research. 
Table 1. Reported work on innovative venom-independent immunization strategies for snake antivenom development.

\begin{tabular}{|c|c|c|c|c|c|c|c|}
\hline Authors \& Year & $\begin{array}{c}\text { Immunization } \\
\text { Strategy }\end{array}$ & Species & Target Toxin(s) & Antivenom & Challenge Toxin(s) & $\begin{array}{c}\text { Effect(s) } \\
\text { Neutralized }\end{array}$ & Ref \\
\hline Čurin-Šerbec et al., 1991 & Synthetic epitope & Vipera ammodytes & Ammodytoxin A & Rabbit antiserum & Ammodytoxin A & Lethality & {$[70]$} \\
\hline Čurin-Šerbec et al., 1994 & Synthetic epitope & $\begin{array}{c}\text { Crotalus durissus } \\
\text { terrificus, } \\
\text { Vipera ammodytes }\end{array}$ & $\begin{array}{l}\text { Crotoxin and } \\
\text { ammodytoxin A }\end{array}$ & Murine IgG, IgM & Crotoxin & $\begin{array}{l}\text { Prolonged } \\
\text { survival time }\end{array}$ & [68] \\
\hline Dolimbek and Atassi, 1996 & Synthetic epitope & $\begin{array}{l}\text { Bungarus } \\
\text { multicinctus }\end{array}$ & $\alpha$-bungarotoxin & Murine antiserum & $\alpha$-bungarotoxin & Lethality & [71] \\
\hline Calderón et al., 1999 & Synthetic epitope & Bothrops asper & Myotoxin II & Murine antiserum & Myotoxin II & Myotoxicity & [67] \\
\hline Harrison et al., 2000 & DNA & Bothrops jararaca & Jararhagin & Murine antiserum & B. jararaca venom & Myotoxicity & [79] \\
\hline Harrison et al., 2002 & DNA & Bothrops jararaca & Jararhagin & Murine antiserum & $\mathrm{N} / \mathrm{A}$ & Not Evaluated & [80] \\
\hline Pergolizzi et al., 2004 & DNA & Naja kaouthia & $\alpha$-cobratoxin & Murine antiserum & $\alpha$-cobratoxin & Lethality & [85] \\
\hline Wagstaff et al., 2006 & DNA & Echis ocellatus & SVMPs & Murine IgG & $\begin{array}{l}\text { E. ocellatus and Cerastes } \\
\text { cerastes venom }\end{array}$ & Hemotoxicity & [83] \\
\hline Ferreira et al., 2006 & Synthetic epitope & Lachesis muta muta & Mutalysin II & Rabbit IgG & Mutalysin II & Hemotoxicity & [69] \\
\hline Azofeifa-Cordero et al., 2008 & DNA & $\begin{array}{l}\text { Crotalus durissus } \\
\text { durissus }\end{array}$ & P-III SVMP & Murine antiserum & C. d. durissus venom & Hemotoxicity & [84] \\
\hline Leão et al., 2009 & DNA & Micrurus corallinus & 3FTx and PLA2s & Murine antiserum & N/A & Not evaluated & {$[95]$} \\
\hline Cardoso et al., 2009 & $\begin{array}{l}\text { Recombinant } \\
\text { mimotope }\end{array}$ & Bothrops neuwiedi & Neuwiedase & Murine antiserum & $\mathrm{N} / \mathrm{A}$ & Not evaluated & {$[78]$} \\
\hline Arce-Estrada et al., 2009 & DNA & Bothrops asper & P-II SVMP & Equine antiserum & $\begin{array}{l}\text { B. asper and C. } d \text {. } \\
\text { durissus venom }\end{array}$ & Hemotoxicity & [82] \\
\hline Suntrarachun et al., 2010 & Recombinant toxin & Bungarus candidus & $\begin{array}{c}\alpha \text { and } \\
\beta \text {-neurotoxins }\end{array}$ & Murine antiserum & B. candidus venom & Lethality & [73] \\
\hline Machado de Avila et al., 2011 & $\begin{array}{l}\text { Synthetic } \\
\text { mimotope }\end{array}$ & Lachesis muta & Mutalysin II & Rabbit antiserum & L. muta venom & Hemotoxicity & [77] \\
\hline Ramos et al., 2016 & $\begin{array}{c}\text { DNA + } \\
\text { Recombinant } \\
\text { protein }\end{array}$ & Micrurus corallinus & 3 FTxs and $\mathrm{PLA}_{2}$ & Murine antiserum & M. corallinus venom & Lethality & [66] \\
\hline Cao et al., 2016 & $\begin{array}{l}\text { Recombinant } \\
\text { protein }\end{array}$ & $\begin{array}{l}\text { Deinagkistrodon } \\
\text { acutus }\end{array}$ & $\begin{array}{l}\text { SVSPs, SVMPs } \\
\text { and } \mathrm{PLA}_{2} \mathrm{~S}\end{array}$ & Murine antiserum & D. acutus venom & Hemotoxicity & {$[72]$} \\
\hline
\end{tabular}


Table 1. Cont

\begin{tabular}{|c|c|c|c|c|c|c|c|}
\hline Authors \& Year & $\begin{array}{c}\text { Immunization } \\
\text { Strategy }\end{array}$ & Species & Target Toxin(s) & Antivenom & Challenge Toxin(s) & $\begin{array}{c}\text { Effect(s) } \\
\text { Neutralized }\end{array}$ & Ref \\
\hline Clement et al., 2016 & Recombinant toxin & Micrurus laticorallis & $\begin{array}{c}\text { Cysteine-rich } \\
\text { neurotoxins } \\
\text { (Mlat1) }\end{array}$ & Rabbit antiserum & M. laticorallis venom & Not neutralizing & [96] \\
\hline Hasson, 2017 & DNA & Echis ocellatus & Disintegrin & Murine antiserum & $\begin{array}{c}\text { Crotalus atrox, E. } \\
\text { ocellatus and Bitis arietans } \\
\text { venom }\end{array}$ & Hemotoxicity & [81] \\
\hline de la Rosa et al., 2018 & Recombinant toxin & $\begin{array}{c}\text { Acanthophis spp., } \\
\text { Oxyuranus spp., } \\
\text { Walterinnesia spp., } \\
\text { Naja spp., } \\
\text { Dendroaspis spp. } \\
\text { and Micrurus spp. }\end{array}$ & $\begin{array}{c}\text { Type I } \\
\alpha \text {-neurotoxins }\end{array}$ & Rabbit antiserum & $\mathrm{N} / \mathrm{A}$ & Not evaluated & {$[75]$} \\
\hline Guerrero-Garzón et al., 2018 & Recombinant toxin & Micrurus diastema & $\begin{array}{c}\text { Type I } \\
\alpha \text {-neurotoxin D.H. }\end{array}$ & Rabbit antiserum & $\begin{array}{l}\mathrm{rD} . \mathrm{H}, \text { MlatA1, and } \\
\text { fraction F5 from } M \text {. } \\
\text { diastema venom }\end{array}$ & Lethality & {$[74]$} \\
\hline
\end{tabular}




\subsection{Studies within Scorpion Antivenom Development}

In the scorpion antivenom field, antivenom producers could benefit from being independent of production animals for venom procurement, as this procedure is quite laborious due to involvement of electrostimulation [16]. As with the snake antivenom field, synthetic epitopes have been developed for immunization research (Table 2, see studies [97-103]). Several studies found varying degrees of antibody-mediated protection against different antigen dosages. In 1986, Bahraoui et al. immunized rabbits with a synthetic peptide of residues 50-59 of Androctonus australis hector toxin II (AahII; a scorpion $\alpha$-toxin) and used the generated antiserum to protect naïve mice against an intracerebroventricular challenge of $14 \mathrm{LD}_{50}$ s of AahII, reporting $80 \%$ protection [97]. Interestingly, the study also reported that conjugation of the synthetic peptide to bovine serum albumin (BSA) resulted in antiserum that did not bind the free native toxins, highlighting that the choice of protein carrier should be considered carefully, and that conjugation to carriers might not be a possibility for all immunogens. Chávez-Olórtegui et al. reported partial protection of naïve mice against the toxic fraction of Tityus serrulatus venom ( $\left.\mathrm{Tst}_{50}\right)$, when subcutaneously injecting the pre-incubated toxic fraction with antiserum derived from rabbits immunized with synthetic peptides derived from the non-toxic protein TsNTxP [104]. Calderón-Aranda et al. immunized rabbits with 7 peptides derived from Centruroides noxius toxin 2 ( $\mathrm{Cn} 2$; a scorpion $\beta$-toxin) and reported $10-80 \%$ protection in naïve mice after these were challenged intraperitoneally with $1 \mathrm{LD}_{50}$ of $\mathrm{Cn} 2$ incubated with the rabbit antiserum [98]. Interestingly, the latter study did not observe immunogenicity of all the utilized epitopes, bringing attention to the need for careful epitope selection and validation [98]. Another study reported full neutralization in naïve mice of up to $39.5 \mathrm{LD}_{50} \mathrm{~S}$ of $\mathrm{Cn} 2$ injected intraperitoneally after incubating $\mathrm{Cn} 2$ with antiserum from rabbits immunized with synthetic epitopes of $\mathrm{Cn} 2$, where also discontinuous epitopes were taken into account [99]. By 2002, Alvarenga and colleagues reported the immunization of rabbits with four epitopes from TsNTxP and one epitope from the major lethal component, TsIV, all conjugated to KLH. The rabbit antiserum was able to neutralize $13.5 \mathrm{LD}_{50} \mathrm{~s}$ of $\mathrm{TstG}_{50}$-fractionated T. serrulatus venom (subcutaneous route) per $\mathrm{mL}$ antiserum in naïve mice [100]. Lastly, rabbits were immunized with an 18-residue peptide from a birtoxin-like $\mathrm{N}$-terminus peptide (conjugated to KLH), and the IgGs were purified and reported to neutralize up to $60 \mathrm{LD}_{99}$ of Parabuthus transvaalicus scorpion venom (intracerebroventricular route) per $\mathrm{mL}$ of IgG [101]. In general, these studies highlight that when selecting epitopes for immunization, focusing on similarity between the most toxic venom components may be highly beneficial. Other than homology, conjugation to KLH seems to be beneficial for increasing the immunization dosages, which may lead to stronger immune responses. This has also been achieved by conjugation of venom components to other protein carriers, such as ovalbumin, BSA, diphtheria toxoid [67], and tetanus toxoid [105]. Lowered toxicity, allowing for increased immunization dosages, can also be achieved by altering the non-epitopic residues, such as it has been done with chimeric toxins, mimotopes, and retro-inverso peptides, as discussed in the next section [98,106,107].

Several studies utilizing recombinant or synthetic toxins/peptides for immunization have reported successful results (Table 2, see studies [106,108-120]). One study found various levels of protection of naïve mice challenged with intraperitoneal or subcutaneous injections of $1-3 L_{50} \mathrm{~s}$ of $\mathrm{Cn} 2$ from C. noxius Hoffmann scorpion venom, when pre-incubated with rabbit antiserum raised against a recombinant $\mathrm{Cn} 5$ (a crustacean-specific toxin) [112]. Zenouaki and colleagues reported 66\% protection of mice challenged with $5 \mathrm{LD}_{50} \mathrm{~s}$ (intracerebroventricular route) of AahII from A. australis hector venom after immunization with a chimeric toxin, where $\alpha$-aminobutyric acid was utilized to replace cysteines [106]. Mendes et al. reported up to $75 \%$ protection against $2 \mathrm{LD}_{50}$ s injected subcutaneously in naïve mice, against $T$. serrulatus scorpion venom, when incubating the scorpion venom with antiserum from immunized rabbits prior to injection into the mice. The rabbits were immunized with recombinant Ts1 toxoids (Ts1 is also called TsVIII or Ts- $\gamma$ ) [114]. Protection of $100 \%$ was furthermore observed when challenging naïve mice subcutaneously with $14 \mathrm{LD}_{50} \mathrm{~s}$ of native Ts1 after pre-incubation with the rabbit antiserum. In another study, rabbits were immunized with AahI, 
AahII, and AahIII fused to maltose-binding protein (MBP), yielding antiserum, which neutralized up to $15 \mathrm{LD}_{50} \mathrm{~s} / \mathrm{mL}$ (subcutaneous route), when incubating the toxic fraction (Aah-G50) of A. australis hector venom with the rabbit antiserum prior to injection into naïve mice. This neutralization capacity was equal to the commercial antivenom available at the time [110]. In the same study, a chimeric toxin consisting of AahI-MBP-AahII was used for immunization of rabbits, but was reported not to bind the native AahI or AahII, indicating that epitopes may lose their immunogenicity if fusion leads to loss of their native conformation, once again highlighting the importance of native-like structures of immunogens for generating antibodies with optimal neutralization capacity [110]. In 1997, 200 $\mathrm{LD}_{50}$ s of AahII per mg of monoclonal antibody was neutralized in naïve mice (intracerebroventricular route), when pre-incubated with purified IgGs from mouse hybridoma cells, where the mice had been immunized with a synthetic AahII toxoid (with $\alpha$-aminobutyric acid replacing cysteines) [108]. Furthermore, another study showed that by immunizing mice with a fusion protein of Bot III and $\mathrm{ZZ}$ domains of staphylococcal protein A, the immunized mice were protected against $10 \mathrm{LD}_{50} \mathrm{~S}$ (subcutaneous route) of the most lethal toxin, Bot III, from Buthus occitanus tunetanus scorpion venom [111]. A study by Jiménez-Vargas and colleagues in 2017 found that antiserum raised against recombinant fusion proteins of thioredoxin-enterokinase cleavage site-Cn2 (Thio-EK-Cn2), Thio-EK-C. suffusus toxin II, and Thio-EK-C. limpidus toxin I or II could neutralize $3 \mathrm{LD}_{50} \mathrm{~s}$ of C. noxius, C. limpidus, C. suffusus, C. tecomanus, C. elegans, and C. sculpturatus scorpion venom in naïve mice, when pre-incubated with just $0.25 \mathrm{~mL}$ of rabbit antiserum and injected intraperitoneally [118]. Lastly, a US patent was granted for the use of 71 gene sequences encoding various scorpion genes for potential DNA immunization, immunization with the corresponding recombinant proteins, or immunoglobulin purification purposes [113]. It is worth mentioning that DNA immunization has yet to be attempted in the scorpion antivenom field.

From the above, it becomes evident that selecting which immunization strategy to use when applying synthetic or recombinant peptides or toxins as immunogens for development of antiserum can be difficult, as results are influenced by several factors. Neutralization capacity depends on the specific IgG titer of the antiserum, which in turn depends on the quantity and immunogenicity of the antigen used for immunization. In addition, the affinity of the antibodies towards the epitopes definitely play a key role. Secondly, the chosen animal model and its intrinsic genetic variance should also be considered. Thus, after optimizing the protocols in small animal species, it is relevant to upscale the protocols to large animals used to manufacture antivenoms. Another factor that makes comparison of antisera particularly challenging is the use of different antiserum volumes and lethal toxin dosages. Standardization in how the protective assays are executed would greatly improve comparability between different methods. 
Table 2. Reported work on innovative venom-independent immunization strategies for scorpion antivenom development.

\begin{tabular}{|c|c|c|c|c|c|c|c|}
\hline Authors \& Year & $\begin{array}{c}\text { Immunization } \\
\text { Strategy }\end{array}$ & Species & Target Toxin(s) & Antivenom & $\begin{array}{l}\text { Challenge } \\
\text { Toxin(s) }\end{array}$ & $\begin{array}{c}\text { Effect(s) } \\
\text { Neutralized }\end{array}$ & Ref. \\
\hline Bahraoui et al., 1986 & Synthetic epitope & $\begin{array}{c}\text { Androctonus australis } \\
\text { hector }\end{array}$ & Toxin II (AahII) & Murine antiserum & AahII & Lethality & [97] \\
\hline Devaux et al., 1993 & Synthetic epitope & $\begin{array}{c}\text { Androctonus australis } \\
\text { hector }\end{array}$ & Toxin II (AahII) & Rabbit antiserum & N/A & $\mathrm{N} / \mathrm{A}$ & [103] \\
\hline Calderón-Aranda et al., 1995 & Synthetic epitope & Centruroides noxius & $\mathrm{Cn} 2$ & $\begin{array}{l}\text { Rabbit and murine } \\
\text { antisera }\end{array}$ & $\mathrm{Cn} 2$ & Lethality & [98] \\
\hline Bouhaouala-Zahar et al., 1996 & Recombinant toxin & $\begin{array}{l}\text { Buthus occitanus } \\
\text { tunetanus }\end{array}$ & $\alpha$-toxin & Murine antiserum & Bot and AaHG & Lethality & [121] \\
\hline Devaux et al., 1997 & Synthetic peptide & $\begin{array}{l}\text { Androctonus australis } \\
\text { hector }\end{array}$ & Toxin II (AahII) & Murine IgG & AahII & Lethality & [108] \\
\hline Zenouaki et al., 1997 & Synthetic peptide & $\begin{array}{l}\text { Androctonus australis } \\
\text { hector }\end{array}$ & Toxin II (AahII) & Rabbit antiserum & AahII & Lethality & [106] \\
\hline Calderón-Aranda et al., 1999 & Synthetic epitope & Centruroides noxius & $\mathrm{Cn} 2$ & $\begin{array}{l}\text { Rabbit and murine } \\
\text { antisera }\end{array}$ & $\mathrm{Cn} 2$ & Lethality & [99] \\
\hline Guatimosim et al., 2000 & Recombinant toxoid & Tityus serrulatus & TsNTxP & Rabbit antiserum & T. serrulatus venom & Lethality & [109] \\
\hline Gazarian et al., 2000 & Mimotopes & $\begin{array}{c}\text { Centruroides noxius } \\
\text { Hoffmann }\end{array}$ & Noxiustoxin & Murine antiserum & N/A & $\mathrm{N} / \mathrm{A}$ & [122] \\
\hline Chávez-Olórtegui et al., 2001 & Synthetic epitope & Tityus serrulatus & TsNTxP & Rabbit antiserum & TstG50 & Lethality & [104] \\
\hline Legros et al., 2001 & Recombinant toxin & $\begin{array}{c}\text { Androctonus australis } \\
\text { hector }\end{array}$ & $\begin{array}{l}\text { AahI, AahII and } \\
\text { AahIII ( } \alpha \text {-toxins) }\end{array}$ & $\begin{array}{l}\text { Rabbit and murine } \\
\text { antisera }\end{array}$ & AaH-G50 & Lethality & [110] \\
\hline Benkhadir et al., 2002 & Recombinant toxin & $\begin{array}{l}\text { Buthus occitanus } \\
\text { tunetanus }\end{array}$ & Bot III ( $\alpha$-toxin) & Murine antiserum & $\begin{array}{c}\text { B. occitanus } \\
\text { tunetanus venom }\end{array}$ & Lethality & [111] \\
\hline Alvarenga et al., 2002 & Synthetic epitope & Tityus serrulatus & TsNTxP and TsIV & Rabbit antiserum & TstG50 & Lethality & [100] \\
\hline Garcia et al., 2003 & Recombinant toxin & $\begin{array}{l}\text { Centruroides noxius } \\
\text { Hoffmann }\end{array}$ & $\begin{array}{l}\text { Cn5 and } \\
\text { sub-fraction }\end{array}$ & Rabbit antiserum & $\mathrm{Cn} 2$ & Lethality & [112] \\
\hline Inceoglu et al., 2006 & Synthetic epitope & Parabuthus transvaalicus & Birtoxin & $\begin{array}{l}\text { Rabbit polyclonal } \\
\text { IgG }\end{array}$ & $\begin{array}{l}\text { P. transvaalicus } \\
\text { venom }\end{array}$ & Lethality & [101] \\
\hline
\end{tabular}


Table 2. Cont

\begin{tabular}{|c|c|c|c|c|c|c|c|}
\hline Authors \& Year & $\begin{array}{c}\text { Immunization } \\
\text { Strategy }\end{array}$ & Species & Target Toxin(s) & Antivenom & $\begin{array}{l}\text { Challenge } \\
\text { Toxin(s) }\end{array}$ & $\begin{array}{c}\text { Effect(s) } \\
\text { Neutralized }\end{array}$ & Ref. \\
\hline Corona Villegas et al., 2008 & Recombinant toxin & Centruroides spp. & $\begin{array}{c}\text { Cex1-13, Cll3-8, } \\
\text { Cn4b, Cn10b, Ce3, } \\
\text { Ce5-7, Ce13(b), } \\
\text { Cg1-3, CsEv1-3, } \\
\text { CsEV8-9, CsE1x, } \\
\text { CsEIa, CexErg1-4, } \\
\text { Cll Erg1-4, Cn } \\
\text { Erg3-5, CeErg1-3, } \\
\text { CgErg1-3, } \\
\text { CsErg1-5 }\end{array}$ & Rabbit antiserum & $\mathrm{Cn} 2$ & Lethality & [113] \\
\hline Mendes et al., 2008 & Recombinant toxin & Tityus serrulatus & Ts1 & Rabbit antiserum & $\begin{array}{c}\text { Tst1 and } T . \\
\text { serrulatus venom }\end{array}$ & Lethality & [114] \\
\hline Hernández-Salgado et al., 2009 & $\begin{array}{l}\text { Recombinant toxin } \\
\text { and toxoid }\end{array}$ & $\begin{array}{c}\text { Centruroides suffusus } \\
\text { suffusus }\end{array}$ & CssII & Rabbit antiserum & $\begin{array}{l}\text { CssII, Cn2, and C. } \\
\text { suffusus suffusus } \\
\text { venom }\end{array}$ & Lethality & [115] \\
\hline García-Gómez et al., 2009 & Recombinant toxin & Parabuthus granulatus & $\operatorname{Pg} 8$ & Murine antiserum & $\begin{array}{c}\text { Pg8 and } P . \\
\text { granulatus venom }\end{array}$ & Lethality & [116] \\
\hline Duarte et al., 2010 & Synthetic epitope & Tityus serrulatus & TsNTxP & Murine antiserum & T. serrulatus venom & Lethality & [102] \\
\hline Eskandari et al., 2014 & Recombinant toxin & Mesobuthus eupeus & BMK neurotoxin & Murine antiserum & $\mathrm{N} / \mathrm{A}$ & Not evaluated & [117] \\
\hline Uawonggul et al., 2014 & Recombinant toxin & Heterometrus laoticus & $\begin{array}{l}\text { Heteroscorpine-1 } \\
\text { (HS-1) }\end{array}$ & Murine antiserum & H. laoticus venom & Paralysis & [120] \\
\hline Jiménez-Vargas et al., 2017 & Recombinant toxin & Centruroides spp. & $\begin{array}{l}\text { Cn2, Css2, Cll1, } \\
\text { and Cll2 }\end{array}$ & $\begin{array}{l}\text { Murine and rabbit } \\
\text { antisera }\end{array}$ & $\begin{array}{c}\text { C. noxius, C. } \\
\text { suffusus, } C \text {. } \\
\text { limpidus, C. elegans, } \\
\text { C. tecomanus, and } \\
\text { C. sculpturatus } \\
\text { venom }\end{array}$ & Lethality & [118] \\
\hline Safari Foroushani et al., 2018 & Recombinant toxoid & Hemiscorpius lepturus & rPLD1 & Murine antiserum & $\begin{array}{l}\text { rPLD1 and } H . \\
\text { lepturus venom }\end{array}$ & Lethality & [119] \\
\hline
\end{tabular}




\subsection{Studies within Spider Antivenom Development}

Production of spider antivenom stands to greatly benefit from innovative immunization approaches, as sufficient amounts of venom are hard to procure due to animal maintenance and laborious venom extraction by electrostimulation [123-125]. In this antivenom field, synthetic toxins [126], recombinant toxins [124-135], synthetic epitopes [107,136,137], and a synthetic mimotope [138] have been used as venom-independent immunization techniques for spider antivenom development. An overview of the different studies is presented in Table 3.

Several studies have reported partial neutralization when utilizing synthetic or recombinant toxins for immunization. Successfully raised antibody responses have yielded antisera, which were tested against venoms or native toxins at different dosages of venom/toxin. For instance, Felicori et al. produced the recombinant dermonecrotic protein I (rLiD1) from Loxosceles intermedia and utilized it as an immunogen in mice. A protection of $75 \%$ was reported when the immunized mice were later challenged subcutaneously with $2.5 \mathrm{LD}_{50} \mathrm{~s}$ of rLiD1 [129]. Conversely, Magalhães et al. reported a $65 \%$ reduction in inflammation and almost complete abolishment of dermonecrosis in naïve rabbits after incubation of Loxosceles gaucho spider venom with rabbit antiserum, raised against a recombinant phospholipase D (LgRec1), natively from L. gaucho spider venom [124]. More studies report full neutralization of Loxosceles sp. venom [127,128,134,139], of which one study reported the development of a more effective antiserum than an existing commercial antivenom on the spider antivenom market. In this study, the antiserum was raised against a sphingomyelinase D in horses and tested in rabbits challenged with L. intermedia, L. laeta, and L. gaucho spider venom, demonstrating neutralization capacity [130].

In 2009, Comis and colleagues reported the use of a synthetic robustoxin from Atrax robustus venom, which had been conjugated to KLH and chemically deactivated by preventing disulfide bridge formation, as an immunogen in Macaca fascicularis monkeys. After 15 weeks, the immunized monkeys survived a subsequent challenge of $50 \mu \mathrm{g} / \mathrm{kg}$ of A. robustus spider venom [126]. Furthermore, Oliveira et al. evaluated the utilization of transgenic mice (engineered to have human MHC class II) for immunization purposes, where the collected murine antisera raised against recombinant sphingomyelinase D (rLid1) were able to inhibit $87 \%$ of edema and to neutralize dermonecrosis and hemotoxicity in naïve rabbits [135].

In studies that utilized synthetic epitopes or mimotopes for immunization, mostly the immunized animals were challenged with venom or native toxins $[107,125,137,138]$. In one of these studies, Fischer and colleagues reversed the primary sequence of robustoxin from $A$. robustus venom and inverted all the chiral centers, yielding a proteolysis-resistant peptide that could be administered orally or intraperitoneally. This method was shown to generate an immune response that saved 7 out of 8 immunized mice [107]. Interestingly, in 2011, de Moura et al. observed that the epitope of LiD1 recognized by a previously reported monoclonal antibody could not be identified by a SPOT epitope-scan. By screening a peptide library via phage display, de Moura et al. found a mimotope mimicking a discontinuous epitope [138]. The mimotope was recognized by the monoclonal antibody and utilized for immunization by liposomal delivery (cholesterol and phosphatidylcholine), which generated an immune response in rabbits. The immunized rabbits were subsequently challenged with $10 \mu \mathrm{g}$ of L. intermedia spider venom. Here, $60 \%$ dermonecrotic protection, $80 \%$ protection against hemorrhage, and higher protection against edema than rabbits immunized with the L. intermedia spider venom was reported [138]. More studies have utilized discontinuous epitopes as well [77,99,126,131, 140].

Three studies by Mendes, Figueiredo, Lima, and colleagues in 2013, 2014, and 2018, respectively, report the usage of a multiepitopic protein for immunization, of which at least one epitope is discontinuous [125,131,132]. This multiepitopic protein protected immunized mice against an intraperitoneal challenge of $2.5 \mathrm{LD}_{50} \mathrm{~s}$ of $L$. intermedia spider venom [125]. The multiepitopic approach proved to generate antiserum with equal neutralization capacity of L. intermedia spider venom, as immunization with the recombinant LiD1 toxin alone, except for edema neutralization [131]. 
Future studies will show if the approach can be utilized to incorporate epitopes from toxins across several spider species and see if they can yield a protective antiserum against the chosen species [125]. This latter approach could, in the future, be attempted in other antivenom fields. Perhaps, by increasing the size of the recombinant protein, immunogenicity of the individual epitopes could be increased. However, a possible obstacle in designing multiepitopic proteins may be ensuring proper epitope folding, and here, linker length might play an essential role [141]. As with the scorpion antivenom field, the spider antivenom development field has yet to explore DNA immunization.

The success of immunizing with recombinant toxins to generate antivenom seems to be determined by the immunogenicity of the immunogen [136], immunization dosages (linked to toxicity), and careful selection of epitopes, which is critical for immunization [136]. Likewise, homology to other toxins in the same venom seems to be important for high neutralization capacity [101]. In order to increase antiserum efficacy and cross-reactivity to closely related toxins from other species, selecting epitopes with high homology to such other toxin components is important [101,109]. However, the utilization of consensus toxins could be a better way to ensure cross-reactivity across homologous toxins, regardless of evolutionary relatedness [75]. 
Table 3. Reported work on innovative venom-independent immunization strategies for spider antivenom development.

\begin{tabular}{|c|c|c|c|c|c|c|c|}
\hline Authors \& Year & $\begin{array}{c}\text { Immunization } \\
\text { Strategy }\end{array}$ & Species & Target Toxin(s) & Antivenom & Challenge Toxin(s) & $\begin{array}{c}\text { Effect(s) } \\
\text { Neutralized }\end{array}$ & Ref. \\
\hline Fernandes Pedrosa et al., 2002 & Recombinant toxin & Loxosceles laeta & Smase I & Rabbit antiserum & $\begin{array}{l}\text { rSmase I and L. laeta } \\
\text { venom }\end{array}$ & Dermonecrosis & [139] \\
\hline Araujo et al., 2003 & Recombinant toxin & Loxosceles intermedia & $\begin{array}{c}\text { Dermonecrotic } \\
\text { toxin }\end{array}$ & Murine antiserum & L. intermedia venom & $\begin{array}{c}\text { Dermonecrosis } \\
\text { and lethality }\end{array}$ & [127] \\
\hline Tambourgi et al., 2004 & Recombinant toxin & Loxosceles intermedia & Sphingomyelinases & Rabbit antiserum & $\mathrm{N} / \mathrm{A}$ & $\mathrm{N} / \mathrm{A}$ & [123] \\
\hline Olvera et al., 2006 & Recombinant toxin & $\begin{array}{l}\text { Loxosceles reclusa, } \\
\text { Loxosceles boneti, } \\
\text { Loxosceles laeta }\end{array}$ & $\begin{array}{l}\text { Sphingomyelinase } \\
\text { D }\end{array}$ & $\begin{array}{l}\text { Rabbit antiserum } \\
\text { and equine } \mathrm{F}\left(\mathrm{ab}^{\prime}\right)_{2}\end{array}$ & $\begin{array}{l}\text { rSMD, } L \text {. reclusa, } L . \\
\text { boneti and } L . \text { laeta venom }\end{array}$ & Lethality & [128] \\
\hline Felicori et al., 2006 & Recombinant toxin & Loxosceles intermedia & $\begin{array}{l}\text { Dermonecrotic } \\
\text { toxin LiD1 }\end{array}$ & Murine antiserum & L. intermedia venom & Lethality & [129] \\
\hline Fischer et al., 2007 & Synthetic epitope & Atrax robustus & Robustoxin & Murine antiserum & A. robustus venom & Lethality & [107] \\
\hline de Almeida et al., 2008 & Recombinant toxin & $\begin{array}{l}\text { Loxosceles intermedia, } \\
\text { Loxosceles laeta and } \\
\text { Loxosceles gaucho }\end{array}$ & $\begin{array}{l}\text { Sphingomyelinase } \\
\text { D }\end{array}$ & Equine antiserum & $\begin{array}{l}\text { L. intermedia, L. laeta, } \\
\text { and L. gaucho venom }\end{array}$ & Dermonecrosis & [130] \\
\hline Felicori et al., 2009 & Synthetic epitope & Loxosceles intermedia & $\begin{array}{l}\text { Dermonecrotic } \\
\text { toxin LiD1 }\end{array}$ & Rabbit IgGs & LiD1 & $\begin{array}{l}\text { Dermonecrosis, } \\
\text { hemotoxicity, and } \\
\text { edema }\end{array}$ & [136] \\
\hline Comis et al., 2009 & Synthetic toxin & Atrax robustus & Robustoxin & Monkey antiserum & A. robustus venom & Lethality & [126] \\
\hline Dias-Lopes et al., 2010 & Synthetic epitope & Loxosceles intermedia & $\begin{array}{l}\text { Dermonecrotic } \\
\text { toxin LiD1 }\end{array}$ & $\begin{array}{l}\text { Rabbit and murine } \\
\text { antisera }\end{array}$ & $\begin{array}{l}\text { rLiD1 and } L . \text { intermedia } \\
\text { venom }\end{array}$ & $\begin{array}{c}\text { Dermonecrosis, } \\
\text { hemotoxicity, and } \\
\text { lethality }\end{array}$ & [137] \\
\hline Chaim et al., 2011 & $\begin{array}{l}\text { Recombinant } \\
\text { toxoid }\end{array}$ & Loxosceles intermedia & $\begin{array}{l}\text { Dermonecrotic } \\
\text { toxin LiD1 }\end{array}$ & Rabbit antiserum & N/A & N/A & [142] \\
\hline de Moura et al., 2011 & $\begin{array}{l}\text { Synthetic } \\
\text { mimotope }\end{array}$ & Loxosceles intermedia & $\begin{array}{l}\text { Dermonecrotic } \\
\text { toxin LiD1 }\end{array}$ & Rabbit antiserum & L. intermedia venom & $\begin{array}{l}\text { Dermonecrosis, } \\
\text { hemotoxicity }\end{array}$ & [138] \\
\hline Mendes et al., 2013 & Recombinant toxin & Loxosceles intermedia & $\begin{array}{l}\text { Dermonecrotic } \\
\text { toxin LiD1 }\end{array}$ & $\begin{array}{l}\text { Rabbit antiserum } \\
\text { and IgG }\end{array}$ & rLiD1 & $\begin{array}{l}\text { Dermonecrosis, } \\
\text { hemotoxicity }\end{array}$ & [131] \\
\hline Magalhães et al., 2013 & Recombinant toxin & Loxosceles gaucho & Phospholipase D & Rabbit antiserum & $\begin{array}{l}\text { LgRec1 and } L . \text { gaucho } \\
\text { venom }\end{array}$ & $\begin{array}{l}\text { Dermonecrosis, } \\
\text { local reaction }\end{array}$ & [124] \\
\hline Figueiredo et al., 2014 & Recombinant toxin & $\begin{array}{l}\text { Loxosceles intermedia, } \\
\text { Loxosceles laeta, and } \\
\text { Loxosceles gaucho }\end{array}$ & $\begin{array}{c}\text { Sphingomyelinase } \\
\text { D }\end{array}$ & Equine antiserum & $\begin{array}{l}\text { L. intermedia, L. gaucho } \\
\text { and L. laeta venom }\end{array}$ & Dermonecrosis & [132] \\
\hline
\end{tabular}


Table 3. Cont

\begin{tabular}{|c|c|c|c|c|c|c|c|}
\hline Authors \& Year & $\begin{array}{c}\text { Immunization } \\
\text { Strategy }\end{array}$ & Species & Target Toxin(s) & Antivenom & Challenge Toxin(s) & $\begin{array}{c}\text { Effect(s) } \\
\text { Neutralized }\end{array}$ & Ref. \\
\hline Dias-Lopes et al., 2014 & Recombinant toxin & $\begin{array}{l}\text { Loxosceles intermedia, } \\
\text { Loxosceles laeta, and } \\
\text { Loxosceles gaucho }\end{array}$ & $\begin{array}{c}\text { Sphingomyelinase } \\
\text { D }\end{array}$ & Murine IgG & rLiD1 & $\begin{array}{c}\text { Dermonecrosis, } \\
\text { hemotoxicity, and } \\
\text { edema }\end{array}$ & [133] \\
\hline Duarte et al., 2015 & Recombinant toxin & $\begin{array}{l}\text { Loxosceles intermedia and } \\
\text { Loxosceles laeta }\end{array}$ & $\begin{array}{l}\text { Dermonecrotic } \\
\text { toxin LiD1 }\end{array}$ & Equine antiserum & $\begin{array}{l}\text { L. intermedia and L. laeta } \\
\text { venom }\end{array}$ & $\begin{array}{l}\text { Dermonecrosis, } \\
\text { hemotoxicity }\end{array}$ & [134] \\
\hline Oliveira et al., 2016 & Recombinant toxin & Loxosceles intermedia & $\begin{array}{c}\text { Sphingomyelinase } \\
\text { D (SMD) }\end{array}$ & Murine antiserum & $\begin{array}{l}\text { rSMDs, } L . \text { reclusa, } L \text {. } \\
\text { boneti, and } L \text {. laeta } \\
\text { venom }\end{array}$ & Lethality & [135] \\
\hline Lima et al., 2018 & Recombinant toxin & $\begin{array}{l}\text { Loxosceles intermedia and } \\
\text { Loxosceles laeta }\end{array}$ & $\begin{array}{c}\text { Loxosceles } \\
\text { astacin-like } \\
\text { protease 1, } \\
\text { hyaluronidases, } \\
\text { SMase-I }\end{array}$ & Rabbit antiserum & L. intermedia venom & Lethality & [125] \\
\hline
\end{tabular}




\section{Alternative Venom-Dependent Immunization Approaches}

Other than venom-independent strategies, immunization approaches utilizing whole venom, venom-derived toxin fractions, or purified toxins from venom that have been chemically deactivated (toxoids) have also been investigated. Within the venom-dependent approaches, novel delivery systems, adjuvants, and detoxification strategies have been introduced to enhance immune responses and antibody neutralization capacity. In relation to delivery systems, already by 1985, New and colleagues employed sphingomyelin-cholesterol liposomes to encapsulate Echis carinatus snake venom, in order to raise an efficacious immune response in mice, rabbits, and sheep [143]. Other studies also utilized liposomes with successful results [77,144-149]. For instance, in 1988, Laing et al. encapsulated E. carinatus snake venom in sphingomyelin-cholesterol liposomes, and utilized these to immunize mice [144]. Likewise, Freitas et al. reported immunization of mice and rabbits with encapsulated Crotalus durissus snake venom, providing better protection than antiserum generated by conventional methods (i.e., using Freund's complete adjuvant), whilst also using 3 times lower quantity of antigen [145]. In 1991, Chávez-Olórtegui encapsulated Tityus serrulatus scorpion venom in sphingomyelin-cholesterol liposomes and used these for immunization of mice, which yielded an antiserum that provided protection in 3 out of 4 naïve mice, when these were challenged with T. serrulatus scorpion venom [146]. In 1993, Laing \& Theakston demonstrated protection in immunized mice against $4.3 \mathrm{LD}_{50} \mathrm{~s}$ (subcutaneous route) of E. ocellatus venom after immunization with venom and lipopolysaccharide (LPS) encapsulated in membrane-stabilized reverse phase evaporation liposomes [147]. Fonseca et al. also reported immunization of mice with encapsulated T. serrulatus scorpion venom, providing antiserum with neutralization capacity of up to $3 \mathrm{LD}_{50} \mathrm{~s}$ (subcutaneous route) against Tst-G50 in naïve mice [148].

Other venom-dependent immunization strategies that have been investigated include the utilization of cross-linked chitosan, calcium-alginate, or poly (D,L-lactide) polymer nanoparticles [150-153]. Cross-linked chitosan nanoparticles were used to encapsulate T. serrulatus scorpion venom for immunization of mice, resulting in antigen-specific murine antiserum with IgG titers equal to antisera raised by immunization using an aluminum hydroxide adjuvant [150]. Similar results were achieved by encapsulating Bothrops jararaca and B. erythromelas snake venom [153], and in another study, calcium-alginate nanoparticles were used to encapsulate $A$. australis hector scorpion venom and applied for immunization of rabbits. The immunized rabbits were protected when challenged subcutaneously with 6 $\mathrm{LD}_{50} \mathrm{~S}$ of $A$. australis hector scorpion venom [151]. Lastly, lethality was reported neutralized in naïve mice, when pre-incubating whole venom with murine antiserum from different mice immunized with either A. australis hector (258 $\mu \mathrm{g}$ venom neutralized per $\mathrm{mL}$ antiserum) or Buthus occitanus tunetanus (186 $\mu \mathrm{g}$ venom neutralized per $\mathrm{mL}$ antiserum) scorpion venoms and injected by the intracerebroventricular route, where immunogens were encapsulated in poly (D,L-lactide) polymers [152]. Variations in the design of emulsions used as adjuvants have also proven to impact the immune response of animals towards snake venoms [154]. As such, optimization of immunization strategies involves the study of immunological modulation of some venoms affecting the response to other venoms, e.g., when co-immunizing with B. asper and Lachesis stenophrys snake venoms (see for example [155]). Such knowledge allows for the improved design of immunization protocols, whereby different venoms are injected into animals at different times to avoid such negative modulation.

A third venom-dependent approach that has been investigated has included chemical deactivation of whole venom or toxin fractions used to generate antiserum with an increased neutralization capacity, by enabling higher immunization dosages due to lowered toxicity. This deactivation has been mediated by gamma radiation [156-159], reaction with glutaraldehyde [160-163], iodination [164,165], alkylation [166], or reaction with formaldehyde [119]. In 1998, very high neutralization capacities were reported by Heneine \& Heneine, who used rabbit antiserum to neutralize up to $30 \mathrm{LD}_{50} \mathrm{~s}$ of T. serrulatus scorpion venom in vitro [165]. Likewise, C. durissus terrificus snake venom was also iodinated and used for immunization, yielding horse antiserum that protected naïve mice against a challenge of $1.33 \mathrm{mg}$ of $C$. durissus terrificus snake venom. In the same study, B. jararaca snake 
venom was also iodinated and used for immunization of horses, yielding an antivenom that could neutralize $13.7 \mathrm{mg}$ of $B$. jararaca snake venom per $\mathrm{mL}$ in naïve mice [165]. These impressive numbers were obtained by abrogating the toxicity of the antigen by gradual iodination, ensuring iodination of tyrosine and histidine residues. The iodination did not oxidize side chains of other amino acids, e.g., indole side chains of tryptophan residues, which may otherwise bring unwanted side effects, such as lowered immunogenicity or antibodies specific against non-native toxins. In this way, Heneine \& Heneine obtained detoxified monomeric T. serrulatus toxins with assumed conserved epitopes, without experiencing protein aggregation [165].

\section{Alternative Immunization Approaches from Other Research Fields}

In other fields, many new immunization or vaccination approaches have been investigated, which could be used as inspiration for antivenom development, with a few selected examples provided in the following. One approach involves the utilization of extracellular vesicles as a novel delivery system, which can even contain MHC complexes when derived from dendritic cells [167]. It has also been suggested that microvesicles normally carrying nucleic acids could be engineered to carry DNA for immunization [167].

Another new delivery approach that has been studied utilizes bacterial ghosts [168-170], where a native bacterial outer membrane (with or without LPS [170]) is utilized to encapsulate the desired antigen. This was reported to be effective in inducing dendritic cell maturation in comparison to LPS-based protocols [168], but may carry the risk of a too-low specific antibody titer. A third approach has been to use nanocarriers to encapsulate an antigenic payload [91,171-173]. Active nanocarriers are encapsulating nanoparticles with incorporated molecules for targeting purposes. A nanocarrier could for instance incorporate an anti-DC-SIGN/CD209a antibody in the nanocarrier membrane, targeting the vesicle for the mouse DC-SIGN/CD209a receptor on the surface of bone marrow-derived dendritic cells (and macrophages). Schetters et al. reported in 2018 specific targeting of mDC-SIGN ${ }^{+}$ skin dendritic cells upon subcutaneous injection of an OVA-coupled anti-mDC-SIGN antibody, leading to a strong anti-OVA response in vivo [174].

A fourth approach has involved conjugation of the desired antigen to virus-like particles (VLPs), wherein different conjugation techniques have been tested. Fusion proteins and chemical conjugation have been applied for this purpose, but even though much research has gone into this field, few licensed VLP-based vaccines have been marketed [175]. The use of VLP-based vaccines has been extensively reviewed elsewhere [175], but worth highlighting is the bacterial superglue SpyTag/SpyCatcher conjugation method, which has already been used for the development of candidate cancer [176] and malaria vaccines [177,178], among others. In 2014, this technology was used to induce potent $\mathrm{B}$ and $\mathrm{T}$ cell responses by targeting dendritic cells with specific model antigens. Here, functional synthetic vaccines were assembled by spontaneous conjugation of the targeting vector (i.e., a dendritic cell-targeting antibody fragment fused to SpyTag) and the payload (i.e., an antigen fused to SpyCatcher) [179].

A last approach to be mentioned here is the use of the adenylate cyclase toxin, CyaA, from Bordetella pertussis, which mediates translocation of its genetically engineerable N-terminus into the cytoplasmic site of eukaryotic cells with which it is in close proximity [180]. The CyaA toxin has further been engineered to deliver antigens into APCs in vivo, after which epitopes of the antigen have been reported to be confirmed displayed on the MHC I and II complexes of the targeted APCs [180]. In the future, CyaA can be combined with ex vivo dendrite cell vaccinations, where dendrites are cultured ex vivo and re-introduced to the patient [181] (or re-introduced to animals for the production of antivenom), for a more direct targeting approach, but may not be feasible for industrial scale-up in antivenom manufacture. 


\section{Biochemical, Bioinformatic, and Omics Tools that Could Aid Antivenom Development}

Due to the complex composition of snake, scorpion, and spider venoms [33,182], the development of next-generation antivenoms is not a trivial matter. Regardless of the developmental strategy explored, it has become a necessity to establish which toxins researchers should focus on to achieve neutralization of venom toxicity [42,183]. To achieve this, biochemical, bioinformatic, and omics tools can be utilized to assist the process of antivenom development. The determination of key toxin targets involves a two-step process. First, a detailed overview of venom composition(s) is required. For this purpose, venom proteomics analysis (i.e., venomics) can be performed. Venomics allows for the identification and quantification of venom components by combining venom fractionation using high performance liquid chromatography and gel electrophoresis with mass spectrometry [40,47,184-187]. A more comprehensive venom profile can be obtained by integrating proteomics with genomic and transcriptomic data [30,188], although mRNA transcription and protein expression levels do not always correlate well [189]. Second, venomics data should be complemented with in vivo toxicity studies of each toxin or venom fraction (i.e., toxicovenomics) to determine which components are crucial for toxicity (Figure 3a) [190-192]. Using both venomics and toxicovenomics data, it is possible to select specific key toxins based on their relative medical importance [42], and exclusively use these to immunize animals. 
(a) Toxicovenomics

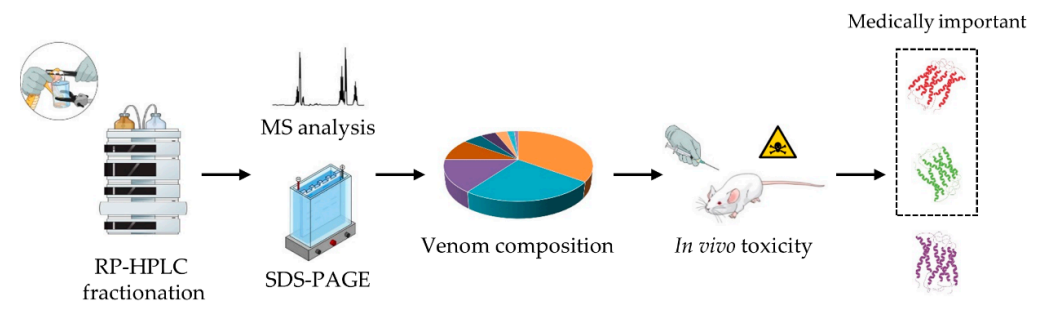

(b) Bioinformatics

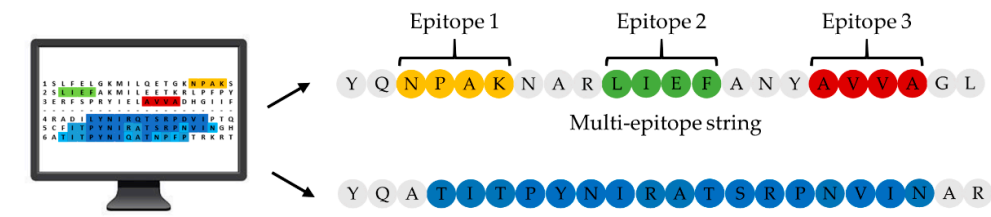

Amino acid sequence analysis

Consensus toxin sequence

(c) Antivenomics

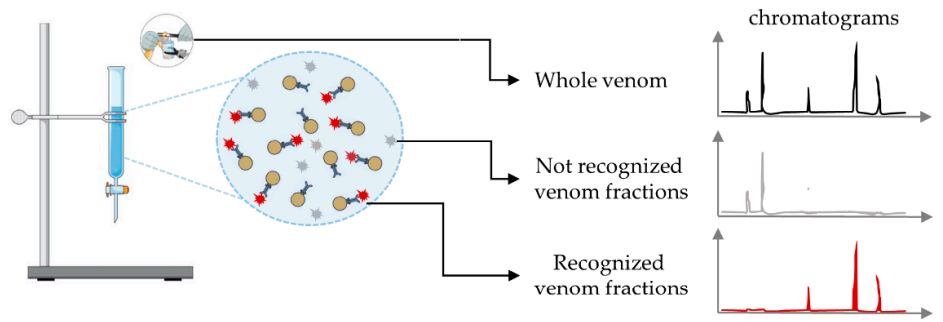

(d) High-density peptide microarray technology

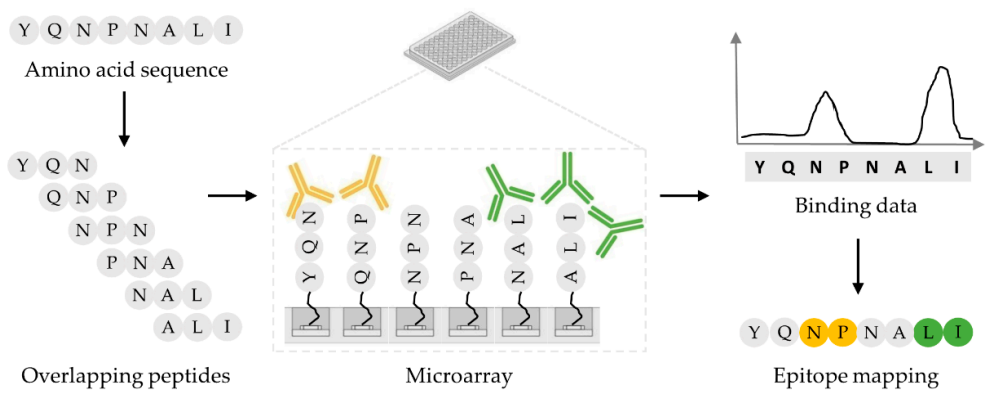

Figure 3. Schematic illustration of biochemical, bioinformatic, and omics tools that could aid antivenom development. (a) Toxicovenomics: Venom composition is determined through venomics. Here, venom is fractionated by reversed-phase high-performance liquid chromatography (RP-HPLC). Subsequently, components of each venom fraction are identified by combining sodium dodecyl sulfate-polyacrylamide gel electrophoresis (SDS-PAGE) and mass spectrometry (MS) analysis. The toxicity of each venom fraction is evaluated in vivo to identify the medically relevant components an antivenom should target. (b) Bioinformatics: Online resources can be used for in silico prediction of epitopic elements and regions of homology from toxin sequences. Predicted epitopes and homologous regions can then be utilized to generate multi-epitopic strings or consensus toxin sequences, respectively. Such strategies aim at generating an immune response against multiple toxins using a single molecule or to generate cross-reactive antibodies. (c) Antivenomics: This approach is employed to assess antivenom reactivity and cross-reactivity based on immunoaffinity. By comparing the chromatographic profiles of whole venom, unbound, and bound venom components, it is possible to discriminate between venom fractions recognized and not recognized by antivenom antibodies. (d) High-density peptide microarray technology: Short overlapping peptides from toxin amino acid sequences are synthesized to study epitope-paratope interactions at an amino acid level by incubating the peptides with antivenom antibodies. This strategy can be used to map epitopes or to assess antivenom reactivity and cross-reactivity in a high-throughput manner. 
In search for key toxin targets, nowadays, numerous web servers for in silico prediction of continuous and/or discontinuous epitopic elements have been developed (reviewed in [193-200]). Based on either amino acid sequence analysis [201-208] or 3D-structural data [205,209-212], these bioinformatic resources circumvent the expensive and time-consuming experimental procedures previously employed for epitope mapping (Figure 3b). Localizing the immunogenic region of toxins may allow for the synthesis of small peptides that could be used as synthetic epitopes for immunization. Generally, neutralizing antibodies target epitopes that are three-dimensional structures that may contain discontinuous epitopic elements [213]. However, some continuous epitopic elements are still able to raise a protective immune response, as extensively exemplified by the studies reported in Tables 1-3. In addition, shortening the size of the required antigen has opened the possibility of generating recombinant epitope strings, in which immunization with a single molecule can give rise to an immune response against multiple toxins [66,72,125]. Bioinformatic tools have also been applied for identification of regions of homology between toxins belonging to the same family to determine consensus toxin sequences $[75,83]$. Immunization with proteins derived from consensus sequences aims towards generating cross-reactive antibodies (i.e., antibodies with the ability to recognize multiple structurally similar toxins), ideally with cross-neutralization potential.

Cross-neutralizing antibodies are of utmost value, since they could be used to formulate polyvalent antivenoms [30]. Besides the classical ELISA and enzymatic neutralization assays employed for in vitro assessment of antivenom reactivity and cross-reactivity, more recently, antivenomics has been employed for this purpose (Figure 3c). Basically, whole venom is passed through a chromatographic column to which antivenom antibodies have been immobilized to. Due to immunoaffinity, venom components recognized by antivenom antibodies are captured. Therefore, by comparing the chromatographic profiles of whole venom, unbound, and bound venom components, antivenomics can be used to determine which toxins the antivenom has the capacity to bind $[26,40,214-217]$. Despite providing a detailed overview of the antivenom's reactivity against individual venom toxins, this strategy does not give precise information about the epitopic elements involved in toxin-antibody interactions. In order to increase the resolution of epitope-paratope interactions, high-density peptide microarray technology has recently been implemented in antivenom research (Figure 3d). With this technology, the immunoreactivity of antivenoms against numerous continuous epitopic elements derived from toxin sequences can be evaluated at an amino acid level in a high-throughput manner [218-220]. Although cross-neutralization strictly needs to be assessed in in vivo studies, antivenomics and high-density peptide microarray technology allow for comprehensive analysis of antivenom cross-reactivity in a rapid and relatively inexpensive way [30]. These tools may thus provide important guidance for directing the development of novel antivenoms [30].

\section{Conclusions}

Improving the efficacy, safety, and affordability of antivenoms against animal envenomings should be a key priority to enable better treatment of these diseases that particularly affect impoverished victims in the rural tropics [12,221-224]. In the far future, a possibility may exist for introducing novel antivenom products based on recombinantly produced antibodies or small molecule inhibitors $[35,36,225,226]$. However, immediate improvements are also warranted, where innovative, venom-independent immunization approaches offer the potential of quick adaptability, as they are compatible with existing antivenom manufacturing setups. In addition, by circumventing the need for venom in antivenom manufacture, the complications associated with animal captivity and venom collection are to some extent limited.

Antivenom development by means of novel immunization approaches has been possible due to the growing knowledge on venom compositions and toxicity obtained through different omics technologies and other biotechnological tools, such as epitope mapping and recombinant expression of heterologous proteins. Such approaches could particularly be used to improve efficacy (higher 
therapeutic antibody titers) [33] and to broaden the neutralization capacity of antivenoms to cover species for which none of the currently available antivenoms work [227]. Improving these properties may in turn lead to improved affordability for envenomed victims, as fewer antivenom vials with a higher content of therapeutic antibodies would be needed to treat an envenoming. Moreover, broadening the neutralization capacity of antivenoms could possibly warrant larger manufacturing outputs, thereby decreasing cost of manufacture per vial. However, despite the numerous accounts of the successful use of novel immunization strategies reported by different antivenom research laboratories, very few of these strategies have found their way to the industrial setting. In the future, the possibility also exists that a combination of innovative immunization strategies with transgenic animals expressing the human antibody repertoire [228-231] could be employed in antivenom manufacture. This may not improve efficacy or affordability, however, it may indeed provide safer antivenoms, as the therapeutic antibodies would be of human, rather than animal origin. Improving safety may even allow for earlier administration of antivenom to victims, which could possibly improve treatment and recovery, due to a lowered risk of adverse reactions.

Author Contributions: E.B.M., A.F.M., S.F., and A.H.L. wrote the manuscript. All authors contributed to editing, correction, and discussions on scientific content. E.B.M. prepared the figures.

Funding: This research received no external funding.

Conflicts of Interest: The authors declare no conflict of interest.

\section{References}

1. Gutiérrez, J.M.; Theakston, R.D.G.; Warrell, D.A. Confronting the neglected problem of snake bite envenoming: The need for a global partnership. PLoS Med. 2006, 3, e150. [CrossRef] [PubMed]

2. World Health Organization. Rabies and Envenomings: A Neglected Public Health Issue: Report of A Consultative Meeting; World Health Organization: Geneva, Switzerland, 2007; ISBN 9789241563482.

3. Diaz, J.H. The global epidemiology, syndromic classification, management, and prevention of spider bites. Am. J. Trop. Med. Hyg. 2004, 71, 239-250. [CrossRef] [PubMed]

4. Chippaux, J.P. Snake-bites: Appraisal of the global situation. Bull. World Health Organ. 1998, 76, 515-524. [PubMed]

5. Kasturiratne, A.; Wickremasinghe, A.R.; de Silva, N.; Gunawardena, N.K.; Pathmeswaran, A.; Premaratna, R.; Savioli, L.; Lalloo, D.G.; de Silva, H.J. The global burden of snakebite: A literature analysis and modelling based on regional estimates of envenoming and deaths. PLoS Med. 2008, 5, e218. [CrossRef] [PubMed]

6. Gutiérrez, J.M.; Calvete, J.J.; Habib, A.G.; Harrison, R.A.; Williams, D.J.; Warrell, D.A. Snakebite envenoming. Nat. Rev. Dis. Primer 2017, 3, 17063. [CrossRef] [PubMed]

7. Chippaux, J.-P.; Goyffon, M. Epidemiology of scorpionism: A global appraisal. Acta Trop. 2008, 107, 71-79. [CrossRef] [PubMed]

8. Bochner, R. Paths to the discovery of antivenom serotherapy in France. J. Venom. Anim. Toxins Trop. Dis. 2016, 22, 20. [CrossRef] [PubMed]

9. Gutiérrez, J.M.; León, G.; Burnouf, T. Antivenoms for the treatment of snakebite envenomings: The road ahead. Biologicals 2011, 39, 129-142. [CrossRef] [PubMed]

10. Theakston, R.D.; Warrell, D.A. Crisis in snake antivenom supply for Africa. Lancet 2000, 356, 2104. [CrossRef]

11. Brown, N.; Landon, J. Antivenom: The most cost-effective treatment in the world? Toxicon 2010, 55, 1405-1407. [CrossRef] [PubMed]

12. Williams, D.J.; Gutiérrez, J.-M.; Calvete, J.J.; Wüster, W.; Ratanabanangkoon, K.; Paiva, O.; Brown, N.I.; Casewell, N.R.; Harrison, R.A.; Rowley, P.D.; et al. Ending the drought: New strategies for improving the flow of affordable, effective antivenoms in Asia and Africa. J. Proteomics 2011, 74, 1735-1767. [CrossRef] [PubMed]

13. Chacón, D.; Rodríguez, S.; Arias, J.; Solano, G.; Bonilla, F.; Gómez, A. Maintaining Coral Snakes (Micrurus nigrocinctus, Serpentes: Elapidae) for venom production on an alternative fish-based diet. Toxicon 2012, 60, 249-253. [CrossRef] [PubMed] 
14. Lalloo, D.G.; Theakston, R.D.G. Snake antivenoms. J. Toxicol. Clin. Toxicol. 2003, 41, 277-290. [CrossRef] [PubMed]

15. Oukkache, N.; Chgoury, F.; Lalaoui, M.; Cano, A.A.; Ghalim, N. Comparison between two methods of scorpion venom milking in Morocco. J. Venom. Anim. Toxins Trop. Dis. 2013, 19, 5. [CrossRef] [PubMed]

16. Meadows, P.E.; Russell, F.E. Milking of arthropods. Toxicon 1970, 8, 311-312. [CrossRef]

17. Rojas, G.; Jiménez, J.M.; Gutiérrez, J.M. Caprylic acid fractionation of hyperimmune horse plasma: Description of a simple procedure for antivenom production. Toxicon 1994, 32, 351-363. [CrossRef]

18. World Health Organization. WHO Guidelines for the Production, Control and Regulation of Snake Antivenom Immunoglobulins; Blood Products and Related Biologicals Quality and Safety: Essential Medicines and Pharmaceutical Policies Health Systems and Services; World Health Organization: Geneva, Switzerland, 2010; ISBN 2105-0678.

19. León, G.; Vargas, M.; Segura, Á.; Herrera, M.; Villalta, M.; Sánchez, A.; Solano, G.; Gómez, A.; Sánchez, M.; Estrada, R.; et al. Current technology for the industrial manufacture of snake antivenoms. Toxicon 2018, 151, 63-73. [CrossRef] [PubMed]

20. Gutiérrez, J.M.; León, G.; Lomonte, B.; Angulo, Y. Antivenoms for snakebite envenomings. Inflamm. Allergy Drug Targets 2011, 10, 369-380. [CrossRef] [PubMed]

21. Segura, A.; Herrera, M.; Villalta, M.; Vargas, M.; Gutiérrez, J.M.; León, G. Assessment of snake antivenom purity by comparing physicochemical and immunochemical methods. Biologicals 2013, 41, 93-97. [CrossRef] [PubMed]

22. Rawat, S.; Laing, G.; Smith, D.C.; Theakston, D.; Landon, J. A new antivenom to treat eastern coral snake (Micrurus fulvius fulvius) envenoming. Toxicon 1994, 32, 185-190. [CrossRef]

23. BTG International Inc. CroFab crotalidae polyvalent immune fab (ovine)—Highlights of Prescribing Information 2017. Available online: https:/ / www.fda.gov / downloads/BloodBloodProducts/ucm117573. pdf (accessed on 8 August 2018).

24. Antúnez, J.; Fernández, J.; Lomonte, B.; Angulo, Y.; Sanz, L.; Pérez, A.; Calvete, J.J.; Gutiérrez, J.M. Antivenomics of Atropoides mexicanus and Atropoides picadoi snake venoms: Relationship to the neutralization of toxic and enzymatic activities. J. Venom Res. 2010, 1, 8-17. [PubMed]

25. Fernández, J.; Alape-Girón, A.; Angulo, Y.; Sanz, L.; Gutiérrez, J.M.; Calvete, J.J.; Lomonte, B. Venomic and antivenomic analyses of the Central American coral snake, Micrurus nigrocinctus (Elapidae). J. Proteome Res. 2011, 10, 1816-1827. [CrossRef] [PubMed]

26. Lomonte, B.; Escolano, J.; Fernández, J.; Sanz, L.; Angulo, Y.; Gutiérrez, J.M.; Calvete, J.J. Snake venomics and antivenomics of the arboreal neotropical pitvipers Bothriechis lateralis and Bothriechis schlegelii. J. Proteome Res. 2008, 7, 2445-2457. [CrossRef] [PubMed]

27. Laustsen, A.H.; Lomonte, B.; Lohse, B.; Fernández, J.; Gutiérrez, J.M. Unveiling the nature of black mamba (Dendroaspis polylepis) venom through venomics and antivenom immunoprofiling: Identification of key toxin targets for antivenom development. J. Proteomics 2015, 119, 126-142. [CrossRef] [PubMed]

28. Judge, R.K.; Henry, P.J.; Mirtschin, P.; Jelinek, G.; Wilce, J.A. Toxins not neutralized by brown snake antivenom. Toxicol. Appl. Pharmacol. 2006, 213, 117-125. [CrossRef] [PubMed]

29. Carmo, A.O.; Chatzaki, M.; Horta, C.C.R.; Magalhães, B.F.; Oliveira-Mendes, B.B.R.; Chávez-Olórtegui, C.; Kalapothakis, E. Evolution of alternative methodologies of scorpion antivenoms production. Toxicon 2015, 97, 64-74. [CrossRef] [PubMed]

30. Laustsen, A.H. Guiding recombinant antivenom development by omics technologies. New Biotechnol. 2017. [CrossRef] [PubMed]

31. Alvarenga, L.M.; Zahid, M.; di Tommaso, A.; Juste, M.O.; Aubrey, N.; Billiald, P.; Muzard, J. Engineering venom's toxin-neutralizing antibody fragments and its therapeutic potential. Toxins 2014, 6, 2541-2567. [CrossRef] [PubMed]

32. Laustsen, A.H.; Engmark, M.; Milbo, C.; Johannesen, J.; Lomonte, B.; Gutiérrez, J.M.; Lohse, B. From Fangs to Pharmacology: The Future of Snakebite Envenoming Therapy. Curr. Pharm. Des. 2016, 22, 5270-5293. [CrossRef] [PubMed]

33. Laustsen, A.H.; Solà, M.; Jappe, E.C.; Oscoz, S.; Lauridsen, L.P.; Engmark, M. Biotechnological Trends in Spider and Scorpion Antivenom Development. Toxins 2016, 8, 226. [CrossRef] [PubMed] 
34. El-Aziz, T.M.A.; Ravelet, C.; Molgo, J.; Fiore, E.; Pale, S.; Amar, M.; Al-Khoury, S.; Dejeu, J.; Fadl, M.; Ronjat, M.; et al. Efficient functional neutralization of lethal peptide toxins in vivo by oligonucleotides. Sci. Rep. 2017, 7, 7202. [CrossRef] [PubMed]

35. Laustsen, A.H.; Gutiérrez, J.M.; Knudsen, C.; Johansen, K.H.; Bermúdez-Méndez, E.; Cerni, F.A.; Jürgensen, J.A.; Ledsgaard, L.; Martos-Esteban, A.; Øhlenschlæger, M.; et al. Pros and cons of different therapeutic antibody formats for recombinant antivenom development. Toxicon 2018, 146, 151-175. [CrossRef] [PubMed]

36. Knudsen, C.; Laustsen, A.H. Recent Advances in Next Generation Snakebite Antivenoms. Trop. Med. Infect. Dis. 2018, 3, 42. [CrossRef] [PubMed]

37. Bulfone, T.C.; Samuel, S.P.; Bickler, P.E.; Lewin, M.R. Developing Small Molecule Therapeutics for the Initial and Adjunctive Treatment of Snakebite. J. Trop. Med. 2018, 2018, 10. [CrossRef] [PubMed]

38. Sannaningaiah, D.; Subbaiah, G.K.; Kempaiah, K. Pharmacology of spider venom toxins. Toxin Rev. 2014, 33, 206-220. [CrossRef]

39. Isbister, G.K.; Bawaskar, H.S. Scorpion Envenomation. N. Engl. J. Med. 2014, 371, 457-463. [CrossRef] [PubMed]

40. Calvete, J.J.; Sanz, L.; Angulo, Y.; Lomonte, B.; Gutiérrez, J.M. Venoms, venomics, antivenomics. FEBS Lett. 2009, 583, 1736-1743. [CrossRef] [PubMed]

41. Abdel-Rahman, M.A.; Harrison, P.L.; Strong, P.N. Snapshots of scorpion venomics. J. Arid Environ. 2015, 112, 170-176. [CrossRef]

42. Laustsen, A.H.; Lohse, B.; Lomonte, B.; Engmark, M.; Gutiérrez, J.M. Selecting key toxins for focused development of elapid snake antivenoms and inhibitors guided by a Toxicity Score. Toxicon 2015, 104, 43-45. [CrossRef] [PubMed]

43. Laustsen, A.H.; Engmark, M.; Clouser, C.; Timberlake, S.; Vigneault, F.; Gutiérrez, J.M.; Lomonte, B. Exploration of immunoglobulin transcriptomes from mice immunized with three-finger toxins and phospholipases $\mathrm{A}_{2}$ from the Central American coral snake, Micrurus nigrocinctus. PeerJ 2017, 5, e2924. [CrossRef] [PubMed]

44. Gutiérrez, J.M.; Sanz, L.; Flores-Díaz, M.; Figueroa, L.; Madrigal, M.; Herrera, M.; Villalta, M.; León, G.; Estrada, R.; Borges, A.; et al. Impact of Regional Variation in Bothrops asper Snake Venom on the Design of Antivenoms: Integrating Antivenomics and Neutralization Approaches. J. Proteome Res. 2010, 9, 564-577. [CrossRef] [PubMed]

45. Rangel-Santos, A.C.; Mota, I. Effect of heating on the toxic, immunogenic and immunosuppressive activities of Crotalus durissus terrificus venom. Toxicon 2000, 38, 1451-1457. [CrossRef]

46. Kini, R.M.; Doley, R. Structure, function and evolution of three-finger toxins: Mini proteins with multiple targets. Toxicon 2010, 56, 855-867. [CrossRef] [PubMed]

47. Calvete, J.J. Snake venomics: From the inventory of toxins to biology. Toxicon 2013, 75, 44-62. [CrossRef] [PubMed]

48. Lomonte, B.; Fernández, J.; Sanz, L.; Angulo, Y.; Sasa, M.; Gutiérrez, J.M.; Calvete, J.J. Venomous snakes of Costa Rica: Biological and medical implications of their venom proteomic profiles analyzed through the strategy of snake venomics. J. Proteomics 2014, 105, 323-339. [CrossRef] [PubMed]

49. Harvey, A.L. Twenty years of dendrotoxins. Toxicon 2001, 39, 15-26. [CrossRef]

50. Dubovskii, P.V.; Utkin, Y.N. Cobra Cytotoxins: Structural Organization and Antibacterial Activity. Acta Naturae 2014, 6, 11-18. [PubMed]

51. Montecucco, C.; Gutiérrez, J.M.; Lomonte, B. Cellular pathology induced by snake venom phospholipase $\mathrm{A}_{2}$ myotoxins and neurotoxins: Common aspects of their mechanisms of action. Cell Mol. Life Sci. 2008, 65, 2897-2912. [CrossRef] [PubMed]

52. Kini, R.M. Excitement ahead: Structure, function and mechanism of snake venom phospholipase $\mathrm{A}_{2}$ enzymes. Toxicon 2003, 42, 827-840. [CrossRef] [PubMed]

53. Gutiérrez, J.M.; Escalante, T.; Rucavado, A.; Herrera, C.; Fox, J.W. A Comprehensive View of the Structural and Functional Alterations of Extracellular Matrix by Snake Venom Metalloproteinases (SVMPs): Novel Perspectives on the Pathophysiology of Envenoming. Toxins 2016, 8, 304. [CrossRef] [PubMed]

54. Markland, F.S.; Swenson, S. Snake venom metalloproteinases. Toxicon 2013, 62, 3-18. [CrossRef] [PubMed]

55. Serrano, S.M.T. The long road of research on snake venom serine proteinases. Toxicon 2013, 62, 19-26. [CrossRef] [PubMed] 
56. Harvey, A.L.; Robertson, B. Dendrotoxins: Structure-activity relationships and effects on potassium ion channels. Curr. Med. Chem. 2004, 11, 3065-3072. [CrossRef] [PubMed]

57. Boldrini-França, J.; Cologna, C.T.; Pucca, M.B.; Bordon, K.D.C.F.; Amorim, F.G.; Anjolette, F.A.P.; Cordeiro, F.A.; Wiezel, G.A.; Cerni, F.A.; Pinheiro-Junior, E.L.; et al. Minor snake venom proteins: Structure, function and potential applications. Biochim. Biophys. Acta BBA-Gen. Subj. 2017, 1861, 824-838. [CrossRef] [PubMed]

58. Quintero-Hernández, V.; Jiménez-Vargas, J.M.; Gurrola, G.B.; Valdivia, H.H.F.; Possani, L.D. Scorpion venom components that affect ion-channels function. Toxicon 2013, 76, 328-342. [CrossRef] [PubMed]

59. Isbister, G.K.; White, J. Clinical consequences of spider bites: Recent advances in our understanding. Toxicon 2004, 43, 477-492. [CrossRef] [PubMed]

60. Isbister, G.K.; Fan, H.W. Spider bite. Lancet 2011, 378, 2039-2047. [CrossRef]

61. Nicholson, G.M.; Graudins, A. Spiders of medical importance in the Asia-Pacific: Atracotoxin, latrotoxin and related spider neurotoxins. Clin. Exp. Pharmacol. Physiol. 2002, 29, 785-794. [CrossRef] [PubMed]

62. Tambourgi, D.V.; Gonçalves-de-Andrade, R.M.; van den Berg, C.W. Loxoscelism: From basic research to the proposal of new therapies. Toxicon 2010, 56, 1113-1119. [CrossRef] [PubMed]

63. Nicholson, G.M.; Little, M.J.; Birinyi-Strachan, L.C. Structure and function of $\delta$-atracotoxins: Lethal neurotoxins targeting the voltage-gated sodium channel. Toxicon 2004, 43, 587-599. [CrossRef] [PubMed]

64. Cordeiro, M.D.N.; Diniz, C.R.; Valentim, A.D.C.; von Eickstedt, V.R.D.; Gilroy, J.; Richardson, M. The purification and amino acid sequences of four Tx2 neurotoxins from the venom of the Brazilian 'armed' spider Phoneutria nigriventer (Keys). FEBS Lett. 1992, 310, 153-156. [CrossRef]

65. Matavel, A.; Cruz, J.S.; Penaforte, C.L.; Araújo, D.A.M.; Kalapothakis, E.; Prado, V.F.; Diniz, C.R.; Cordeiro, M.N.; Beirão, P.S.L. Electrophysiological characterization and molecular identification of the Phoneutria nigriventer peptide toxin PnTx2-6 1. FEBS Lett. 2002, 523, 219-223. [CrossRef]

66. Ramos, H.R.; Junqueira-de-Azevedo, I.D.L.M.; Novo, J.B.; Castro, K.; Duarte, C.G.; Machado-de-Ávila, R.A.; Chavez-Olortegui, C.; Ho, P.L. A Heterologous Multiepitope DNA Prime/Recombinant Protein Boost Immunisation Strategy for the Development of an Antiserum against Micrurus corallinus (Coral Snake) Venom. PLoS Negl. Trop. Dis. 2016, 10, e0004484. [CrossRef] [PubMed]

67. Calderón, L.; Lomonte, B. Inhibition of the myotoxic activity of Bothrops asper myotoxin II in mice by immunization with its synthetic 13-mer peptide 115-129. Toxicon 1999, 37, 683-687. [CrossRef]

68. Čurin-Šerbec, V.; Délot, E.; Faure, G.; Saliou, B.; Gubenšek, F.; Bon, C.; Choumet, V. Antipeptide antibodies directed to the C-terminal part of ammodytoxin A react with the PLA 2 subunit of crotoxin and neutralize its pharmacological activity. Toxicon 1994, 32, 1337-1348. [CrossRef]

69. Ferreira, R.N.; Machado de Avila, R.A.; Sanchez, E.F.; Maria, W.S.; Molina, F.; Granier, C.; Chávez-Olórtegui, C. Antibodies against synthetic epitopes inhibit the enzymatic activity of mutalysin II, a metalloproteinase from bushmaster snake venom. Toxicon 2006, 48, 1098-1103. [CrossRef] [PubMed]

70. Čurin-Šerbec, V.; Novak, D.; Babnik, J.; Turk, D.; Gubenšek, F. Immunological studies of the toxic site in ammodytoxin A. FEBS Lett. 1991, 280, 175-178. [CrossRef]

71. Dolimbek, B.Z.; Atassi, M.Z. Protection against alpha-bungarotoxin poisoning by immunization with synthetic toxin peptides. Mol. Immunol. 1996, 33, 681-689. [CrossRef]

72. Cao, Y.-L.; Guo, G.-N.; Zhu, G.-Y.; Tian, Z.; Gou, Y.-J.; Chen, C.; Liu, M.-H. Bioinformatics-based design of novel antigenic B-cell linear epitopes of Deinagkistrodon acutus venom. Eur. Rev. Med. Pharmacol. Sci. 2016, 20, 781-787. [PubMed]

73. Suntrarachun, S.; Tirawatnapong, T.; Khunsap, S.; Puempumpanich, S. cDNA cloning, sequencing, and expression of $\alpha$ - and $\beta$-neurotoxins from Thai-Malayan krait. Indian J. Biotechnol. 2010, 9, 31-37.

74. Guerrero-Garzón, J.F.; Bénard-Valle, M.; Restano-Cassulini, R.; Zamudio, F.; Corzo, G.; Alagón, A.; Olvera-Rodríguez, A. Cloning and sequencing of three-finger toxins from the venom glands of four Micrurus species from Mexico and heterologous expression of an alpha-neurotoxin from Micrurus diastema. Biochimie 2018, 147, 114-121. [CrossRef] [PubMed]

75. De la Rosa, G.; Corrales-García, L.L.; Rodriguez-Ruiz, X.; López-Vera, E.; Corzo, G. Short-chain consensus alpha-neurotoxin: A synthetic 60-mer peptide with generic traits and enhanced immunogenic properties. Amino Acids 2018. [CrossRef] [PubMed] 
76. Lomonte, B.; Rey-Suárez, P.; Fernández, J.; Sasa, M.; Pla, D.; Vargas, N.; Bénard-Valle, M.; Sanz, L.; Corrêa-Netto, C.; Núñez, V.; et al. Venoms of Micrurus coral snakes: Evolutionary trends in compositional patterns emerging from proteomic analyses. Toxicon 2016, 122, 7-25. [CrossRef] [PubMed]

77. De Avila, R.M.; Stransky, S.; Velloso, M.; Castanheira, P.; Schneider, F.S.; Kalapothakis, E.; Sanchez, E.F.; Nguyen, C.; Molina, F.; Granier, C.; et al. Mimotopes of mutalysin-II from Lachesis muta snake venom induce hemorrhage inhibitory antibodies upon vaccination of rabbits. Peptides 2011, 32, 1640-1646. [CrossRef] [PubMed]

78. Cardoso, R.; Homsi-Brandeburgo, M.I.; Rodrigues, V.M.; Santos, W.B.; Souza, G.L.R.; Prudencio, C.R.; Siquieroli, A.C.S.; Goulart, L.R. Peptide mimicking antigenic and immunogenic epitope of neuwiedase from Bothrops neuwiedi snake venom. Toxicon 2009, 53, 254-261. [CrossRef] [PubMed]

79. Harrison, R.A.; Moura-Da-Silva, A.M.; Laing, G.D.; Wu, Y.; Richards, A.; Broadhead, A.; Bianco, A.E.; Theakston, R.D.G. Antibody from mice immunized with DNA encoding the carboxyl-disintegrin and cysteine-rich domain (JD9) of the haemorrhagic metalloprotease, Jararhagin, inhibits the main lethal component of viper venom. Clin. Exp. Immunol. 2000, 121, 358-363. [CrossRef] [PubMed]

80. Harrison, R.A.; Richards, A.; Laing, G.D.; Theakston, R.D.G. Simultaneous GeneGun immunisation with plasmids encoding antigen and GM-CSF: Significant enhancement of murine antivenom IgG1 titres. Vaccine 2002, 20, 1702-1706. [CrossRef]

81. Hasson, S.S.A.A. Generation of antibodies against disintegrin and cysteine-rich domains by DNA immunization: An approach to neutralize snake venom-induced haemorrhage. Asian Pac. J. Trop. Biomed. 2017, 7, 198-207. [CrossRef]

82. Arce-Estrada, V.; Azofeifa-Cordero, G.; Estrada, R.; Alape-Girón, A.; Flores-Díaz, M. Neutralization of venom-induced hemorrhage by equine antibodies raised by immunization with a plasmid encoding a novel P-II metalloproteinase from the lancehead pitviper Bothrops asper. Vaccine 2009, 27, 460-466. [CrossRef] [PubMed]

83. Wagstaff, S.C.; Laing, G.D.; Theakston, R.D.G.; Papaspyridis, C.; Harrison, R.A. Bioinformatics and multiepitope DNA immunization to design rational snake antivenom. PLoS Med. 2006, 3, e184. [CrossRef] [PubMed]

84. Azofeifa-Cordero, G.; Arce-Estrada, V.; Flores-Díaz, M.; Alape-Girón, A. Immunization with cDNA of a novel P-III type metalloproteinase from the rattlesnake Crotalus durissus durissus elicits antibodies which neutralize $69 \%$ of the hemorrhage induced by the whole venom. Toxicon 2008, 52, 302-308. [CrossRef] [PubMed]

85. Pergolizzi, R.G.; Dragos, R.; Ropper, A.; Menez, A.; Crystal, R.G. Development of a Genetic Vaccine Conferring Protective Immunity Against $\alpha$-Cobratoxin Following a Single Administration of an Adenovirus Vector Encoding a Modified, Non-Toxic Cobratoxin Variant. Mol. Ther. 2004, 9, S143. [CrossRef]

86. Bolhassani, A.; Yazdi, S.R. DNA Immunization as an Efficient Strategy for Vaccination. Avicenna J. Med. Biotechnol. 2009, 1, 71-88. [PubMed]

87. Harrison, R.A. Development of venom toxin-specific antibodies by DNA immunisation: Rationale and strategies to improve therapy of viper envenoming. Vaccine 2004, 22, 1648-1655. [CrossRef] [PubMed]

88. Liu, S.; Wang, S.; Lu, S. DNA immunization as a technology platform for monoclonal antibody induction. Emerg. Microbes Infect. 2016, 5, e33. [CrossRef] [PubMed]

89. Liu, W.; Wong, Y.C.; Chen, S.M.Y.; Tang, J.; Wang, H.; Cheung, A.K.L.; Chen, Z. DNA prime/MVTT boost regimen with HIV-1 mosaic Gag enhances the potency of antigen-specific immune responses. Vaccine 2018, 36, 4621-4632. [CrossRef] [PubMed]

90. Perrie, Y.; Frederik, P.M.; Gregoriadis, G. Liposome-mediated DNA vaccination: The effect of vesicle composition. Vaccine 2001, 19, 3301-3310. [CrossRef]

91. Pérez-Herrero, E.; Fernández-Medarde, A. Advanced targeted therapies in cancer: Drug nanocarriers, the future of chemotherapy. Eur. J. Pharm. Biopharm. 2015, 93, 52-79. [CrossRef] [PubMed]

92. Fotoran, W.L.; Santangelo, R.; Miranda, B.N.M.D.; Irvine, D.J.; Wunderlich, G. DNA-Loaded Cationic Liposomes Efficiently Function as a Vaccine against Malarial Proteins. Mol. Ther. Methods Clin. Dev. 2017, 7, 1-10. [CrossRef] [PubMed]

93. Reyes, M.; Ramírez, C.; Nancucheo, I.; Villegas, R.; Schaffeld, G.; Kriman, L.; Gonzalez, J.; Oyarzun, P. A novel "in-feed" delivery platform applied for oral DNA vaccination against IPNV enables high protection in Atlantic salmon (Salmon salar). Vaccine 2017, 35, 626-632. [CrossRef] [PubMed] 
94. Zheng, F.; Liu, H.; Sun, X.; Qin, X.; Xu, Z.; Wang, B. Construction and expression of DNA vaccine against reddish body iridovirus and evaluation of immune efficacy in turbot (Scophthalmus maximus). Aquac. Res. 2017, 48, 4174-4183. [CrossRef]

95. Leão, L.I.; Ho, P.L.; Junqueira-de-Azevedo, I.D.L.M. Transcriptomic basis for an antiserum against Micrurus corallinus (coral snake) venom. BMC Genomics 2009, 10, 112. [CrossRef] [PubMed]

96. Clement, H.; Flores, V.; De la Rosa, G.; Zamudio, F.; Alagon, A.; Corzo, G. Heterologous expression, protein folding and antibody recognition of a neurotoxin from the Mexican coral snake Micrurus laticorallis. J. Venom. Anim. Toxins Trop. Dis. 2016, 22. [CrossRef] [PubMed]

97. Bahraoui, E.M.; Granier, C.; Rietschoten, J.V.; Rochat, H.; El Ayeb, M. Specificity and neutralizing capacity of antibodies elicited by a synthetic peptide of scorpion toxin. J. Immunol. 1986, 136, 3371-3377. [PubMed]

98. Calderón-Aranda, E.S.; Olamendi-Portugal, T.; Possani, L.D. The use of synthetic peptides can be a misleading approach to generate vaccines against scorpion toxins. Vaccine 1995, 13, 1198-1206. [CrossRef]

99. Calderón-Aranda, E.S.; Selisko, B.; York, E.J.; Gurrola, G.B.; Stewart, J.M.; Possani, L.D. Mapping of an epitope recognized by a neutralizing monoclonal antibody specific to toxin $\mathrm{Cn} 2$ from the scorpion Centruroides noxius, using discontinuous synthetic peptides. Eur. J. Biochem. 1999, 264, 746-755. [CrossRef] [PubMed]

100. Alvarenga, L.M.; Diniz, C.R.; Granier, C.; Chávez-Olórtegui, C. Induction of neutralizing antibodies against Tityus serrulatus scorpion toxins by immunization with a mixture of defined synthetic epitopes. Toxicon 2002, 40, 89-95. [CrossRef]

101. Inceoglu, B.; Lango, J.; Rabinovich, A.; Whetstone, P.; Hammock, B.D. The neutralizing effect of a polyclonal antibody raised against the N-terminal eighteen-aminoacid residues of birtoxin towards the whole venom of Parabuthus transvaalicus. Toxicon 2006, 47, 144-149. [CrossRef] [PubMed]

102. Duarte, C.G.; Alvarenga, L.M.; Dias-Lopes, C.; Machado-de-Ávila, R.A.; Nguyen, C.; Molina, F.; Granier, C.; Chávez-Olórtegui, C. In vivo protection against Tityus serrulatus scorpion venom by antibodies raised against a discontinuous synthetic epitope. Vaccine 2010, 28, 1168-1176. [CrossRef] [PubMed]

103. Devaux, C.; Juin, M.; Mansuelle, P.; Granier, C. Fine molecular analysis of the antigenicity of the Androctonus australis hector scorpion neurotoxin II: A new antigenic epitope disclosed by the pepscan method. Mol. Immunol. 1993, 30, 1061-1068. [CrossRef]

104. Chavez-Olortegui, C.; Molina, F.; Granier, C. Molecular basis for the cross-reactivity of antibodies elicited by a natural anatoxin with $\alpha$ - and $\beta$-toxins from the venom of Tityus serrulatus scorpion. Mol. Immunol. 2001, 38, 867-876. [CrossRef]

105. Jarząb, A.; Witkowska, D.; Ziomek, E.; Setner, B.; Czajkowska, A.; Dorot, M.; Szewczuk, Z.; Gamian, A. Cyclic OmpC peptidic epitope conjugated to tetanus toxoid as a potential vaccine candidate against shigellosis. Vaccine 2018, 36, 4641-4649. [CrossRef] [PubMed]

106. Zenouaki, I.; Kharrat, R.; Sabatier, J.-M.; Devaux, C.; Karoui, H.; Van Rietschoten, J.; El Ayeb, M.; Rochat, H. In vivo protection against Androctonus australis hector scorpion toxin and venom by immunization with a synthetic analog of toxin II. Vaccine 1997, 15, 187-194. [CrossRef]

107. Fischer, P.; Comis, A.; Tyler, M.; Howden, M. Oral and parenteral immunization with synthetic retro-inverso peptides induce antibodies that cross-react with native peptides and parent antigens. Indian J. Biochem. Biophys. 2007, 44, 5.

108. Devaux, C.; Clot-Faybesse, O.; Juin, M.; Mabrouk, K.; Sabatier, J.-M.; Rochat, H. Monoclonal antibodies neutralizing the toxin II from Androctonus australis hector scorpion venom: Usefulness of a synthetic, non-toxic analog. FEBS Lett. 1997, 412, 456-460. [CrossRef]

109. Guatimosim, S.C.F.; Kalapothakis, E.; Diniz, C.R.; Chávez-Olórtegui, C. Induction of neutralizing antibodies against Tityus serrulatus toxins by immunization with a recombinant nontoxic protein. Toxicon 2000, 38, 113-121. [CrossRef]

110. Legros, C.; Kaabi, H.; El Ayeb, M.; Céard, B.; Vacher, H.; Bougis, P.E.; Martin-Eauclaire, M.-F. Use of fusion protein constructs to generate potent immunotherapy and protection against scorpion toxins. Vaccine 2001, 20, 934-942. [CrossRef]

111. Benkhadir, K.; Mejri, T.; Bel Haj Rhouma, R.; El Ayeb, M.; Karoui, H. Induction de protection in vivo et in vitro contre l'activite letale du veni de Buthus occitanus tunetanus avec une proteine recombinante. Arch. Inst. Pasteur Tunis 2002, 79, 19-26. [PubMed] 
112. Garcia, C.; Calderón-Aranda, E.S.; Anguiano, G.A.V.; Becerril, B.; Possani, L.D. Analysis of the immune response induced by a scorpion venom sub-fraction, a pure peptide and a recombinant peptide, against toxin Cn2 of Centruroides noxius Hoffmann. Toxicon 2003, 41, 417-427. [CrossRef]

113. Corona Villegas, M.; Garcia Rodríguez, M.C.; Gurrola Briones, G.; Valdez Cruz, N.A.; Becerril Luján, B.; Possani Postay, L.D. Recombinant immunogens for the generation of antivenoms to the venom of scorpions of the genus Centruroides. U.S. Patent 7,335,759 B2, 26 February 2008.

114. Mendes, T.M.; Dias, F.; Horta, C.C.R.; Pena, I.F.; Arantes, E.C.; Kalapothakis, E. Effective Tityus serrulatus anti-venom produced using the Ts1 component. Toxicon 2008, 52, 787-793. [CrossRef] [PubMed]

115. Hernández-Salgado, K.; Estrada, G.; Olvera, A.; Coronas, F.I.; Possani, L.D.; Corzo, G. Heterologous expressed toxic and non-toxic peptide variants of toxin CssII are capable to produce neutralizing antibodies against the venom of the scorpion Centruroides suffusus suffusus. Immunol. Lett. 2009, 125, 93-99. [CrossRef] [PubMed]

116. García-Gómez, B.I.; Olamendi-Portugal, T.C.; Paniagua, J.; van der Walt, J.; Dyason, K.; Possani, L.D. Heterologous expression of a gene that codes for Pg8, a scorpion toxin of Parabuthus granulatus, capable of generating protecting antibodies in mice. Toxicon 2009, 53, 770-778. [CrossRef] [PubMed]

117. Eskandari, G.; Jolodar, A.; Seyfiabad Shapouri, M.R.; Bahmainmehr, A.; Navidpour, S. Production of Recombinant Alpha Neurotoxin of Scorpion Venom Mesobuthus eupeus and Analysis of its Immunogenicity. Iran. Red Crescent Med. J. 2014, 16. [CrossRef] [PubMed]

118. Jiménez-Vargas, J.M.; Quintero-Hernández, V.; González-Morales, L.; Ortiz, E.; Possani, L.D. Design and expression of recombinant toxins from Mexican scorpions of the genus Centruroides for production of antivenoms. Toxicon 2017, 128, 5-14. [CrossRef] [PubMed]

119. Safari Foroushani, N.; Modarressi, M.H.; Behdani, M.; Torabi, E.; Pooshang Bagheri, K.; Shahbazzadeh, D. Developing recombinant phospholipase D1 (rPLD1) toxoid from Iranian Hemiscorpius lepturus scorpion and its protective effects in BALB/c mice. Toxicon 2018, 152, 30-36. [CrossRef] [PubMed]

120. Uawonggul, N.; Sukprasert, S.; Incamnoi, P.; Patramanon, R.; Thammasirirak, S.; Preecharram, S.; Bunyatratchata, W.; Kuaprasert, B.; Daduang, J.; Daduang, S. Bacterial Overexpression of Recombinant Heteroscorpine-1 (rHS-1), a Toxin from Heterometrus laoticus Scorpion Venom: Trends for Antibacterial Application and Antivenom Production. Biochem. Genet. 2014, 52, 459-473. [CrossRef] [PubMed]

121. Bouhaouala-Zahar, B.; Ducancel, F.; Zenouaki, I.; Khalifa, R.B.; Borchani, L.; Pelhate, M.; Boulain, J.-C.; Ayeb, M.E.; Ménez, A.; Karoui, H. A Recombinant Insect-Specific $\alpha$-Toxin of Buthus occitanus tunetanus Scorpion Confers Protection Against Homologous Mammal Toxins. Eur. J. Biochem. 1996, 238, 653-660. [CrossRef] [PubMed]

122. Gazarian, T.; Selisko, B.; Hérion, P.; Gazarian, K. Isolation and structure-functional characterization of phage display library-derived mimotopes of noxiustoxin, a neurotoxin of the scorpion Centruroides noxius Hoffmann. Mol. Immunol. 2000, 37, 755-766. [CrossRef]

123. Tambourgi, D.V.; Pedrosa, M.d.F.F.; van den Berg, C.W.; Gonçalves-de-Andrade, R.M.; Ferracini, M.; Paixão-Cavalcante, D.; Morgan, B.P.; Rushmere, N.K. Molecular cloning, expression, function and immunoreactivities of members of a gene family of sphingomyelinases from Loxosceles venom glands. Mol. Immunol. 2004, 41, 831-840. [CrossRef] [PubMed]

124. Magalhães, G.S.; Caporrino, M.C.; Della-Casa, M.S.; Kimura, L.F.; Prezotto-Neto, J.P.; Fukuda, D.A.; Portes-Junior, J.A.; Neves-Ferreira, A.G.C.; Santoro, M.L.; Barbaro, K.C. Cloning, expression and characterization of a phospholipase D from Loxosceles gaucho venom gland. Biochimie 2013, 95, 1773-1783. [CrossRef] [PubMed]

125. Lima, S.D.A.; Guerra-Duarte, C.; Costal-Oliveira, F.; Mendes, T.M.; Figueiredo, L.F.M.; Oliveira, D.; Machado de Avila, R.A.; Ferrer, V.P.; Trevisan-Silva, D.; Veiga, S.S.; et al. Recombinant Protein Containing B-Cell Epitopes of Different Loxosceles Spider Toxins Generates Neutralizing Antibodies in Immunized Rabbits. Front. Immunol. 2018, 9. [CrossRef] [PubMed]

126. Comis, A.; Tyler, M.; Mylecharane, E.; Spence, I.; Howden, M. Immunization with a synthetic robustoxin derivative lacking disulphide bridges protects against a potentially lethal challenge with funnel-web spider (Atrax robustus) venom. J. Biosci. 2009, 34, 35-44. [CrossRef] [PubMed]

127. Araujo, S.C.; Castanheira, P.; Alvarenga, L.M.; Mangili, O.C.; Kalapothakis, E.; Chávez-Olórtegui, C. Protection against dermonecrotic and lethal activities of Loxosceles intermedia spider venom by immunization with a fused recombinant protein. Toxicon 2003, 41, 261-267. [CrossRef] 
128. Olvera, A.; Ramos-Cerrillo, B.; Estévez, J.; Clement, H.; de Roodt, A.; Paniagua-Solís, J.; Vázquez, H.; Zavaleta, A.; Salas Arruz, M.; Stock, R.P.; et al. North and South American Loxosceles spiders: Development of a polyvalent antivenom with recombinant sphingomyelinases D as antigens. Toxicon 2006, 48, 64-74. [CrossRef] [PubMed]

129. Felicori, L.; Araujo, S.C.; Machado de Ávila, R.A.; Sanchez, E.F.; Granier, C.; Kalapothakis, E.; Chávez-Olórtegui, C. Functional characterization and epitope analysis of a recombinant dermonecrotic protein from Loxosceles intermedia spider. Toxicon 2006, 48, 509-519. [CrossRef] [PubMed]

130. De Almeida, D.M.; Fernandes-Pedrosa, M.D.F.; de Andrade, R.M.G.; Marcelino, J.R.; Gondo-Higashi, H.; de Azevedo, I.D.L.M.J.; Ho, P.L.; van den Berg, C.; Tambourgi, D.V. A new anti-loxoscelic serum produced against recombinant sphingomyelinase D: Results of preclinical trials. Am. J. Trop. Med. Hyg. 2008, 79, 463-470. [CrossRef] [PubMed]

131. Mendes, T.M.; Oliveira, D.; Figueiredo, L.F.M.; Machado-de-Avila, R.A.; Duarte, C.G.; Dias-Lopes, C.; Guimarães, G.; Felicori, L.; Minozzo, J.C.; Chávez-Olortegui, C. Generation and characterization of a recombinant chimeric protein $(\mathrm{rCpLi})$ consisting of B-cell epitopes of a dermonecrotic protein from Loxosceles intermedia spider venom. Vaccine 2013, 31, 2749-2755. [CrossRef] [PubMed]

132. Figueiredo, L.F.M.; Dias-Lopes, C.; Alvarenga, L.M.; Mendes, T.M.; Machado-de-Ávila, R.A.; McCormack, J.; Minozzo, J.C.; Kalapothakis, E.; Chávez-Olórtegui, C. Innovative immunization protocols using chimeric recombinant protein for the production of polyspecific loxoscelic antivenom in horses. Toxicon 2014, 86, 59-67. [CrossRef] [PubMed]

133. Dias-Lopes, C.; Felicori, L.; Rubrecht, L.; Cobo, S.; Molina, L.; Nguyen, C.; Galéa, P.; Granier, C.; Molina, F.; Chávez-Olortegui, C. Generation and molecular characterization of a monoclonal antibody reactive with conserved epitope in sphingomyelinases D from Loxosceles spider venoms. Vaccine 2014, 32, 2086-2092. [CrossRef] [PubMed]

134. Duarte, C.G.; Bonilla, C.; Guimarães, G.; Machado de Avila, R.A.; Mendes, T.M.; Silva, W.; Tintaya, B.; Yarleque, A.; Chávez-Olórtegui, C. Anti-loxoscelic horse serum produced against a recombinant dermonecrotic protein of Brazilian Loxosceles intermedia spider neutralize lethal effects of Loxosceles laeta venom from Peru. Toxicon 2015, 93, 37-40. [CrossRef] [PubMed]

135. Oliveira, C.F.B.; Vilela, A.; Coura, L.A.M.; Rodrigues, F.T.G.; Nagem, R.A.P.; Chávez-Olortegui, C.; Maioli, T.U.; Felicori, L.F. Protective antibodies against a sphingomyelinase D from Loxosceles intermedia spider venom elicited in mice with different genetic background. Vaccine 2016, 34, 3828-3834. [CrossRef] [PubMed]

136. Felicori, L.; Fernandes, P.B.; Giusta, M.S.; Duarte, C.G.; Kalapothakis, E.; Nguyen, C.; Molina, F.; Granier, C.; Chávez-Olórtegui, $\mathrm{C}$. An in vivo protective response against toxic effects of the dermonecrotic protein from Loxosceles intermedia spider venom elicited by synthetic epitopes. Vaccine 2009, 27, 4201-4208. [CrossRef] [PubMed]

137. Dias-Lopes, C.; Guimarães, G.; Felicori, L.; Fernandes, P.; Emery, L.; Kalapothakis, E.; Nguyen, C.; Molina, F.; Granier, C.; Chávez-Olórtegui, C. A protective immune response against lethal, dermonecrotic and hemorrhagic effects of Loxosceles intermedia venom elicited by a 27-residue peptide. Toxicon 2010, 55, 481-487. [CrossRef] [PubMed]

138. De Moura, J.; Felicori, L.; Moreau, V.; Guimarães, G.; Dias-Lopes, C.; Molina, L.; Alvarenga, L.M.; Fernandes, P.; Frézard, F.; Ribeiro, R.R.; et al. Protection against the toxic effects of Loxosceles intermedia spider venom elicited by mimotope peptides. Vaccine 2011, 29, 7992-8001. [CrossRef] [PubMed]

139. Fernandes Pedrosa, M.F.; Junqueira de Azevedo, I.L.; Gonçalves-de-Andrade, R.M.; van den Berg, C.; Ramos, C.R.; Ho, P.L.; Tambourgi, D.V. Molecular cloning and expression of a functional dermonecrotic and haemolytic factor from Loxosceles laeta venom. Biochem. Biophys. Res. Commun. 2002, 298, 638-645. [CrossRef]

140. Chen, S.-W.W.; Van Regenmortel, M.H.V.; Pellequer, J.-L. Structure-activity relationships in peptide-antibody complexes: Implications for epitope prediction and development of synthetic peptide vaccines. Curr. Med. Chem. 2009, 16, 953-964. [CrossRef] [PubMed]

141. Chen, X.; Zaro, J.L.; Shen, W.-C. Fusion protein linkers: Property, design and functionality. Adv. Drug Deliv. Rev. 2013, 65, 1357-1369. [CrossRef] [PubMed]

142. Chaim, O.M.; da Silveira, R.B.; Trevisan-Silva, D.; Ferrer, V.P.; Sade, Y.B.; Bóia-Ferreira, M.; Gremski, L.H.; Gremski, W.; Senff-Ribeiro, A.; Takahashi, H.K.; et al. Phospholipase-D activity and inflammatory response 
induced by brown spider dermonecrotic toxin: Endothelial cell membrane phospholipids as targets for toxicity. Biochim. Biophys. Acta BBA-Mol. Cell Biol. Lipids 2011, 1811, 84-96. [CrossRef] [PubMed]

143. New, R.R.C.; Theakston, R.D.G.; Zumbuehl, O.; Iddon, D.; Friend, J. Liposomal immunisation against snake venoms. Toxicon 1985, 23, 215-219. [CrossRef]

144. Laing, G.; Theakston, R.D.G.; New, R.R.C. Use of liposomes incorporating immunostimulants for immunisation against snake venom. Toxicon 1988, 26, 29. [CrossRef]

145. Freitas, T.V.; Tavares, A.P.; Theakston, R.D.G.; Laing, G.; New, R.R.C. Use of liposomes for protective immunisation against Crotalus durissus (tropical rattlesnake) venom. Toxicon 1989, 27, 341-347. [CrossRef]

146. Chavez-Olortegui, C.; Amara, D.A.; Rochat, H.; Diniz, C.; Granier, C. In vivo protection against scorpion toxins by liposomal immunization. Vaccine 1991, 9, 907-910. [CrossRef]

147. Laing, G.D.; Theakston, R.D. Immunization against Echis ocellatus (carpet viper) venom using liposomes incorporating immunostimulants: Role of lipopolysaccharide in conferring protection in a mouse model. Toxicon 1993, 31, 615-626. [CrossRef]

148. Fonseca, S.G.; Ferreira, A.M.M.; Diniz, C.R.; Chávez-Olórtegui, C. Induction of neutralizing antibodies in mice immunized with scorpion toxins detoxified by liposomal entrapment. Braz. J. Med. Biol. Res. 1997, 30, 883-886. [CrossRef] [PubMed]

149. Carvalho, V.T.; Gomes, R.T.; Viotti, A.P.; Freitas, T.V. Immunization with liposome-encapsulated Bothrops jararaca venom. Toxicon 2000, 38, 881-886. [CrossRef]

150. Rocha Soares, K.S.; Cardozo Fonseca, J.L.; Oliveira Bitencourt, M.A.; Santos, K.S.C.R.; Silva-Júnior, A.A.; Fernandes-Pedrosa, M.F. Serum production against Tityus serrulatus scorpion venom using cross-linked chitosan nanoparticles as immunoadjuvant. Toxicon 2012, 60, 1349-1354. [CrossRef] [PubMed]

151. Nait Mohamed, F.A.; Laraba-Djebari, F. Development and characterization of a new carrier for vaccine delivery based on calcium-alginate nanoparticles: Safe immunoprotective approach against scorpion envenoming. Vaccine 2016, 34, 2692-2699. [CrossRef] [PubMed]

152. Ayari-Riabi, S.; Trimaille, T.; Mabrouk, K.; Bertin, D.; Gigmes, D.; Benlasfar, Z.; Zaghmi, A.; Bouhaouala-Zahar, B.; Elayeb, M. Venom conjugated polylactide applied as biocompatible material for passive and active immunotherapy against scorpion envenomation. Vaccine 2016, 34, 1810-1815. [CrossRef] [PubMed]

153. Soares, K.S.R.; Gláucia-Silva, F.; Daniele-Silva, A.; Torres-Rêgo, M.; Araújo, N.K.D.; Menezes, Y.A.S.D.; Damasceno, I.Z.; Tambourgi, D.V.; da Silva-Júnior, A.A.; Fernandes-Pedrosa, M.D.F. Antivenom Production against Bothrops jararaca and Bothrops erythromelas Snake Venoms Using Cross-Linked Chitosan Nanoparticles as an Immunoadjuvant. Toxins 2018, 10, 158. [CrossRef] [PubMed]

154. Valverde, J.M.; Rodríguez, K.; Herrera, M.; Segura, Á.; Vargas, M.; Villalta, M.; Montero, M.; Gutiérrez, J.M.; León, G. Comparison of the adjuvant activity of emulsions with different physicochemical properties on the antibody response towards the venom of West African carpet viper (Echis ocellatus). Toxicon 2017, 127, 106-111. [CrossRef] [PubMed]

155. Arroyo, C.; Solano, S.; Herrera, M.; Segura, Á.; Estrada, R.; Vargas, M.; Villalta, M.; Gutiérrez, J.M.; León, G. Lachesis stenophrys venom reduces the equine antibody response towards Bothrops asper venom used as co-immunogen in the production of polyspecific snake antivenom. Toxicon 2015, 103, 99-105. [CrossRef] [PubMed]

156. Hati, R.N.; Mandal, M.; Hati, A.K. Active immunization of rabbit with gamma irradiated Russell's viper venom toxoid. Toxicon 1990, 28, 895-902. [CrossRef]

157. Clissa, P.B.; do Nascimento, N.; Rogero, J.R. Toxicity and immunogenicity of Crotalus durissus terrificus venom treated with different doses of gamma rays. Toxicon 1999, 37, 1131-1141. [CrossRef]

158. Abib, L.; Laraba-Djebari, F. Effect of gamma irradiation on toxicity and immunogenicity of Androctonus australis hector venom. Can. J. Physiol. Pharmacol. 2003, 81, 1118-1124. [CrossRef] [PubMed]

159. Abdou, F.; Denshary, E.E.; Shaaban, E.; Mohamed, M. Assessment of the neutralizing potency of antisera raised against native and $\gamma$-irradiated Naja nigricollis (black-necked spitting cobra) venom in rabbits, concerning its cardiotoxic effect. Hum. Exp. Toxicol. 2017, 36, 1335-1344. [CrossRef] [PubMed]

160. Possani, L.D.; de Castro, J.F.; Juliá, J.Z. Detoxification with glutaraldehyde of purified scorpion (Centruroides noxius Hoffmann) venom. Toxicon 1981, 19, 323-329. [CrossRef]

161. Kuo, K.W.; Chang, C.C. High affinity antibody to cobrotoxin prepared from the derivatives of glutaraldehyde-detoxified cobrotoxin. J. Biochem. 1991, 110, 863-867. [CrossRef] [PubMed] 
162. Ferreira, M.G.; Duarte, C.G.; Oliveira, M.S.; Castro, K.L.P.; Teixeira, M.S.; Reis, L.P.G.; Zambrano, J.A.; Kalapothakis, E.; Michel, A.F.R.M.; Soto-Blanco, B.; et al. Toxicity of crude and detoxified Tityus serrulatus venom in anti-venom-producing sheep. J. Vet. Sci. 2016, 17, 467-477. [CrossRef] [PubMed]

163. Kaabi, H.; Kharrat, R.; el Ayeb, M. Study of the protective capacity of scorpion venom Buthus occitanus tunetanus polymerised to glutaraldehyde in mice strains with different haplotypes. Arch. Inst. Pasteur Tunis 2001, 78, 17-23. [PubMed]

164. Heneine, L.G.D.; Cardoso, V.N.; Daniel, J.; Heneine, I.F. Detoxification of the T2 fraction from a scorpion (Tityus serrulatus, Lutz and Mello) venom by iodination and some immunogenic properties of the derivatives. Toxicon 1986, 24, 501-505. [CrossRef]

165. Heneine, I.F.; Heneine, L.G. Stepwise iodination. A general procedure for detoxification of proteins suitable for vaccine development and antiserum production. Biologicals 1998, 26, 25-32. [CrossRef] [PubMed]

166. Soares, A.M.; Sestito, W.P.; Marcussi, S.; Stábeli, R.G.; Andrião-Escarso, S.H.; Cunha, O.A.B.; Vieira, C.A.; Giglio, J.R. Alkylation of myotoxic phospholipases $\mathrm{A}_{2}$ in Bothrops moojeni venom: A promising approach to an enhanced antivenom production. Int. J. Biochem. Cell Biol. 2004, 36, 258-270. [CrossRef]

167. Chulpanova, D.S.; Kitaeva, K.V.; James, V.; Rizvanov, A.A.; Solovyeva, V.V. Therapeutic Prospects of Extracellular Vesicles in Cancer Treatment. Front. Immunol. 2018, 9. [CrossRef] [PubMed]

168. Dobrovolskienė, N.; Pašukonienė, V.; Darinskas, A.; Kraśko, J.A.; Žilionytė, K.; Mlynska, A.; Gudlevičienė, Ž.; Mišeikytė-Kaubrienè, E.; Schijns, V.; Lubitz, W.; et al. Tumor lysate-loaded Bacterial Ghosts as a tool for optimized production of therapeutic dendritic cell-based cancer vaccines. Vaccine 2018, 36, 4171-4180. [CrossRef] [PubMed]

169. Jiao, H.; Yang, H.; Zhao, D.; Chen, J.; Zhang, Q.; Liang, J.; Yin, Y.; Kong, G.; Li, G. Design and immune characterization of a novel Neisseria gonorrhoeae DNA vaccine using bacterial ghosts as vector and adjuvant. Vaccine 2018, 36, 4532-4539. [CrossRef] [PubMed]

170. Pulido, M.R.; García-Quintanilla, M.; Pachón, J.; McConnell, M.J. Immunization with lipopolysaccharide-free outer membrane complexes protects against Acinetobacter baumannii infection. Vaccine 2018, 36, 4153-4156. [CrossRef] [PubMed]

171. Estanqueiro, M.; Amaral, M.H.; Conceição, J.; Sousa Lobo, J.M. Nanotechnological carriers for cancer chemotherapy: The state of the art. Colloids Surf. B Biointerfaces 2015, 126, 631-648. [CrossRef] [PubMed]

172. Biswaro, L.S.; Sousa, G.M.D.C.; Rezende, T.M.B.; Dias, S.C.; Franco, O.L. Antimicrobial Peptides and Nanotechnology, Recent Advances and Challenges. Front. Microbiol. 2018, 9. [CrossRef] [PubMed]

173. Liu, C.; Kou, Y.; Zhang, X.; Cheng, H.; Chen, X.; Mao, S. Strategies and industrial perspectives to improve oral absorption of biological macromolecules. Expert Opin. Drug Deliv. 2018, 15, 223-233. [CrossRef] [PubMed]

174. Schetters, S.T.; Kruijssen, L.J.; Crommentuijn, M.H.; Kalay, H.; Ochando, J.; Den Haan, J.M.; Garcia-Vallejo, J.J.; Van Kooyk, Y. Mouse DC-SIGN/CD209a as Target for Antigen Delivery and Adaptive Immunity. Front. Immunol. 2018, 9. [CrossRef] [PubMed]

175. Brune, K.D.; Howarth, M. New Routes and Opportunities for Modular Construction of Particulate Vaccines: Stick, Click, and Glue. Front. Immunol. 2018, 9. [CrossRef] [PubMed]

176. Palladini, A.; Thrane, S.; Janitzek, C.M.; Pihl, J.; Clemmensen, S.B.; Jongh, W.A.D.; Clausen, T.M.; Nicoletti, G.; Landuzzi, L.; Penichet, M.L.; Balboni, T.; et al. Virus-like particle display of HER2 induces potent anti-cancer responses. OncoImmunology 2018, 7, e1408749. [CrossRef] [PubMed]

177. Singh, S.K.; Thrane, S.; Janitzek, C.M.; Nielsen, M.A.; Theander, T.G.; Theisen, M.; Salanti, A.; Sander, A.F. Improving the malaria transmission-blocking activity of a Plasmodium falciparum $48 / 45$ based vaccine antigen by SpyTag/SpyCatcher mediated virus-like display. Vaccine 2017, 35, 3726-3732. [CrossRef] [PubMed]

178. Thrane, S.; Janitzek, C.M.; Matondo, S.; Resende, M.; Gustavsson, T.; de Jongh, W.A.; Clemmensen, S.; Roeffen, W.; van de Vegte-Bolmer, M.; van Gemert, G.J.; et al. Bacterial superglue enables easy development of efficient virus-like particle based vaccines. J. Nanobiotechnology 2016, 14, 30. [CrossRef] [PubMed]

179. Liu, Z.; Zhou, H.; Wang, W.; Tan, W.; Fu, Y.-X.; Zhu, M. A novel method for synthetic vaccine construction based on protein assembly. Sci. Rep. 2014, 4, 7266. [CrossRef] [PubMed]

180. Chenal, A.; Ladant, D. Bioengineering of Bordetella pertussis Adenylate Cyclase Toxin for Antigen-Delivery and Immunotherapy. Toxins 2018, 10, 302. [CrossRef] [PubMed]

181. Carreno, B.M.; Magrini, V.; Becker-Hapak, M.; Kaabinejadian, S.; Hundal, J.; Petti, A.A.; Ly, A.; Lie, W.-R.; Hildebrand, W.H.; Mardis, E.R.; et al. A dendritic cell vaccine increases the breadth and diversity of melanoma neoantigen-specific T cells. Science 2015, 348, 803-808. [CrossRef] [PubMed] 
182. Tasoulis, T.; Isbister, G.K. A Review and Database of Snake Venom Proteomes. Toxins 2017, 9, 290. [CrossRef] [PubMed]

183. Laustsen, A.H. Toxin-centric development approach for next-generation antivenoms. Toxicon 2018, 150, 195-197. [CrossRef] [PubMed]

184. Gutiérrez, J.M.; Lomonte, B.; León, G.; Alape-Girón, A.; Flores-Díaz, M.; Sanz, L.; Angulo, Y.; Calvete, J.J. Snake venomics and antivenomics: Proteomic tools in the design and control of antivenoms for the treatment of snakebite envenoming. J. Proteomics 2009, 72, 165-182. [CrossRef] [PubMed]

185. Calvete, J.J. Proteomic tools against the neglected pathology of snake bite envenoming. Expert Rev. Proteomics 2011, 8, 739-758. [CrossRef] [PubMed]

186. Calvete, J.J.; Petras, D.; Calderón-Celis, F.; Lomonte, B.; Encinar, J.R.; Sanz-Medel, A. Protein-species quantitative venomics: Looking through a crystal ball. J. Venom. Anim. Toxins Trop. Dis. 2017, 23. [CrossRef] [PubMed]

187. Lomonte, B.; Calvete, J.J. Strategies in 'snake venomics' aiming at an integrative view of compositional, functional, and immunological characteristics of venoms. J. Venom. Anim. Toxins Trop. Dis. 2017, 23. [CrossRef] [PubMed]

188. Calvete, J.J.; Lomonte, B. A bright future for integrative venomics. Toxicon 2015, 107, 159-162. [CrossRef] [PubMed]

189. Haider, S.; Pal, R. Integrated Analysis of Transcriptomic and Proteomic Data. Curr. Genomics 2013, 14, 91-110. [CrossRef] [PubMed]

190. Laustsen, A.H.; Gutiérrez, J.M.; Rasmussen, A.R.; Engmark, M.; Gravlund, P.; Sanders, K.L.; Lohse, B.; Lomonte, B. Danger in the reef: Proteome, toxicity, and neutralization of the venom of the olive sea snake, Aipysurus laevis. Toxicon 2015, 107, 187-196. [CrossRef] [PubMed]

191. Lauridsen, L.P.; Laustsen, A.H.; Lomonte, B.; Gutiérrez, J.M. Toxicovenomics and antivenom profiling of the Eastern green mamba snake (Dendroaspis angusticeps). J. Proteomics 2016, 136, 248-261. [CrossRef] [PubMed]

192. Lauridsen, L.P.; Laustsen, A.H.; Lomonte, B.; Gutiérrez, J.M. Exploring the venom of the forest cobra snake: Toxicovenomics and antivenom profiling of Naja melanoleuca. J. Proteomics 2017, 150, 98-108. [CrossRef] [PubMed]

193. Flower, D.R. Towards in silico prediction of immunogenic epitopes. Trends Immunol. 2003, 24, 667-674. [CrossRef] [PubMed]

194. Yang, X.; Yu, X. An introduction to epitope prediction methods and software. Rev. Med. Virol. 2008, 19, 77-96. [CrossRef] [PubMed]

195. Sun, P.; Ju, H.; Liu, Z.; Ning, Q.; Zhang, J.; Zhao, X.; Huang, Y.; Ma, Z.; Li, Y. Bioinformatics Resources and Tools for Conformational B-Cell Epitope Prediction. Comput. Math. Methods Med. 2013, 2013, 11. [CrossRef] [PubMed]

196. Wang, H.-W.; Pai, T.-W. Machine Learning-Based Methods for Prediction of Linear B-Cell Epitopes. In Immunoinformatics; Methods in Molecular Biology; Humana Press: New York, NY, USA, 2014; pp. 217-236. ISBN 978-1-4939-1114-1.

197. Backert, L.; Kohlbacher, O. Immunoinformatics and epitope prediction in the age of genomic medicine. Genome Med. 2015, 7. [CrossRef] [PubMed]

198. Soria-Guerra, R.E.; Nieto-Gomez, R.; Govea-Alonso, D.O.; Rosales-Mendoza, S. An overview of bioinformatics tools for epitope prediction: Implications on vaccine development. J. Biomed. Inform. 2015, 53, 405-414. [CrossRef] [PubMed]

199. Potocnakova, L.; Bhide, M.; Pulzova, L.B. An Introduction to B-Cell Epitope Mapping and In Silico Epitope Prediction. J. Immunol. Res. 2016, 2016. [CrossRef] [PubMed]

200. EL-Manzalawy, Y.; Dobbs, D.; Honavar, V.G. In Silico Prediction of Linear B-Cell Epitopes on Proteins. In Prediction of Protein Secondary Structure; Methods in Molecular Biology; Humana Press: New York, NY, USA, 2017; pp. 255-264. ISBN 978-1-4939-6404-8.

201. Larsen, J.E.P.; Lund, O.; Nielsen, M. Improved method for predicting linear B-cell epitopes. Immunome Res. 2006, 2, 2. [CrossRef] [PubMed]

202. Saha, S.; Raghava, G.P.S. Prediction of continuous B-cell epitopes in an antigen using recurrent neural network. Proteins Struct. Funct. Bioinform. 2006, 65, 40-48. [CrossRef] [PubMed]

203. Chen, J.; Liu, H.; Yang, J.; Chou, K.-C. Prediction of linear B-cell epitopes using amino acid pair antigenicity scale. Amino Acids 2007, 33, 423-428. [CrossRef] [PubMed] 
204. EL-Manzalawy, Y.; Dobbs, D.; Honavar, V. Predicting linear B-cell epitopes using string kernels. J. Mol. Recognit. 2008, 21, 243-255. [CrossRef] [PubMed]

205. Rubinstein, N.D.; Mayrose, I.; Martz, E.; Pupko, T. Epitopia: A web-server for predicting B-cell epitopes. BMC Bioinform. 2009, 10, 287. [CrossRef] [PubMed]

206. Singh, H.; Ansari, H.R.; Raghava, G.P.S. Improved Method for Linear B-Cell Epitope Prediction Using Antigen's Primary Sequence. PLoS ONE 2013, 8. [CrossRef] [PubMed]

207. Shen, W.; Cao, Y.; Cha, L.; Zhang, X.; Ying, X.; Zhang, W.; Ge, K.; Li, W.; Zhong, L. Predicting linear B-cell epitopes using amino acid anchoring pair composition. BioData Min. 2015, 8. [CrossRef] [PubMed]

208. Jespersen, M.C.; Peters, B.; Nielsen, M.; Marcatili, P. BepiPred-2.0: Improving sequence-based B-cell epitope prediction using conformational epitopes. Nucleic Acids Res. 2017, 45, W24-W29. [CrossRef] [PubMed]

209. Haste Andersen, P.; Nielsen, M.; Lund, O. Prediction of residues in discontinuous B-cell epitopes using protein 3D structures. Protein Sci. Publ. Protein Soc. 2006, 15, 2558-2567. [CrossRef] [PubMed]

210. Ponomarenko, J.; Bui, H.-H.; Li, W.; Fusseder, N.; Bourne, P.E.; Sette, A.; Peters, B. ElliPro: A new structure-based tool for the prediction of antibody epitopes. BMC Bioinform. 2008, 9, 514. [CrossRef] [PubMed]

211. Kringelum, J.V.; Lundegaard, C.; Lund, O.; Nielsen, M. Reliable B Cell Epitope Predictions: Impacts of Method Development and Improved Benchmarking. PLoS Comput. Biol. 2012, 8, e1002829. [CrossRef] [PubMed]

212. Krawczyk, K.; Liu, X.; Baker, T.; Shi, J.; Deane, C.M. Improving B-cell epitope prediction and its application to global antibody-antigen docking. Bioinformatics 2014, 30, 2288-2294. [CrossRef] [PubMed]

213. Ledsgaard, L.; Jenkins, T.P.; Davidsen, K.; Krause, K.E.; Martos-Esteban, A.; Engmark, M.; Rørdam Andersen, M.; Lund, O.; Laustsen, A.H. Antibody Cross-Reactivity in Antivenom Research. Toxins 2018, 10, 393. [CrossRef] [PubMed]

214. Pla, D.; Gutiérrez, J.M.; Calvete, J.J. Second generation snake antivenomics: Comparing immunoaffinity and immunodepletion protocols. Toxicon 2012, 60, 688-699. [CrossRef] [PubMed]

215. Gutiérrez, J.M.; Lomonte, B.; Sanz, L.; Calvete, J.J.; Pla, D. Immunological profile of antivenoms: Preclinical analysis of the efficacy of a polyspecific antivenom through antivenomics and neutralization assays. J. Proteomics 2014, 105, 340-350. [CrossRef] [PubMed]

216. Calvete, J.J.; Sanz, L.; Pla, D.; Lomonte, B.; Gutiérrez, J.M. Omics Meets Biology: Application to the Design and Preclinical Assessment of Antivenoms. Toxins 2014, 6, 3388-3405. [CrossRef] [PubMed]

217. Pla, D.; Rodríguez, Y.; Calvete, J.J. Third Generation Antivenomics: Pushing the Limits of the In Vitro Preclinical Assessment of Antivenoms. Toxins 2017, 9, 158. [CrossRef]

218. Engmark, M.; Andersen, M.R.; Laustsen, A.H.; Patel, J.; Sullivan, E.; Masi, F.D.; Hansen, C.S.; Kringelum, J.V.; Lomonte, B.; Gutiérrez, J.M.; et al. High-throughput immuno-profiling of mamba (Dendroaspis) venom toxin epitopes using high-density peptide microarrays. Sci. Rep. 2016, 6, 36629. [CrossRef] [PubMed]

219. Engmark, M.; Lomonte, B.; Gutiérrez, J.M.; Laustsen, A.H.; Masi, F.D.; Andersen, M.R.; Lund, O. Cross-recognition of a pit viper (Crotalinae) polyspecific antivenom explored through high-density peptide microarray epitope mapping. PLoS Negl. Trop. Dis. 2017, 11, e0005768. [CrossRef] [PubMed]

220. Engmark, M.; Jespersen, M.C.; Lomonte, B.; Lund, O.; Laustsen, A.H. High-density peptide microarray exploration of the antibody response in a rabbit immunized with a neurotoxic venom fraction. Toxicon 2017, 138, 151-158. [CrossRef] [PubMed]

221. Harrison, R.A.; Hargreaves, A.; Wagstaff, S.C.; Faragher, B.; Lalloo, D.G. Snake Envenoming: A Disease of Poverty. PLoS Negl. Trop. Dis. 2009, 3, e569. [CrossRef] [PubMed]

222. Harrison, R.A.; Gutiérrez, J.M. Priority Actions and Progress to Substantially and Sustainably Reduce the Mortality, Morbidity and Socioeconomic Burden of Tropical Snakebite. Toxins 2016, 8, 351. [CrossRef] [PubMed]

223. Bawaskar, H.S.; Bawaskar, P.H.; Bawaskar, P.H. Snake bite in India: A neglected disease of poverty. Lancet 2017, 390, 1947-1948. [CrossRef]

224. Laustsen, A.H.; Dorrestijn, N. Integrating Engineering, Manufacturing, and Regulatory Considerations in the Development of Novel Antivenoms. Toxins 2018, 10, 309. [CrossRef] [PubMed]

225. Laustsen, A.H. Snakebites: Costing recombinant antivenoms. Nature 2016, 538, 41. [CrossRef] [PubMed] 
226. Laustsen, A.H.; Johansen, K.H.; Engmark, M.; Andersen, M.R. Recombinant snakebite antivenoms: A cost-competitive solution to a neglected tropical disease? PLoS Negl. Trop. Dis. 2017, 11, e0005361. [CrossRef] [PubMed]

227. Longbottom, J.; Shearer, F.M.; Devine, M.; Alcoba, G.; Chappuis, F.; Weiss, D.J.; Ray, S.E.; Ray, N.; Warrell, D.A.; de Castañeda, R.R.; et al. Vulnerability to snakebite envenoming: A global mapping of hotspots. Lancet 2018. [CrossRef]

228. Brüggemann, M.; Osborn, M.J.; Ma, B.; Hayre, J.; Avis, S.; Lundstrom, B.; Buelow, R. Human Antibody Production in Transgenic Animals. Arch. Immunol. Ther. Exp. 2015, 63, 101-108. [CrossRef] [PubMed]

229. Cervenak, J.; Kurrle, R.; Kacskovics, I. Accelerating antibody discovery using transgenic animals overexpressing the neonatal Fc receptor as a result of augmented humoral immunity. Immunol. Rev. 2015, 268, 269-287. [CrossRef] [PubMed]

230. Chiu, M.L.; Gilliland, G.L. Engineering antibody therapeutics. Curr. Opin. Struct. Biol. 2016, 38, $163-173$. [CrossRef] [PubMed]

231. Chen, W.C.; Murawsky, C.M. Strategies for Generating Diverse Antibody Repertoires Using Transgenic Animals Expressing Human Antibodies. Front. Immunol. 2018, 9. [CrossRef] [PubMed]

(C) 2018 by the authors. Licensee MDPI, Basel, Switzerland. This article is an open access article distributed under the terms and conditions of the Creative Commons Attribution (CC BY) license (http:/ / creativecommons.org/licenses/by/4.0/). 